\title{
Chemical Constituents with Inhibitory Activities on Proprotein Convertase Subtilisin/kexin Type 9 Expression from the Aerial Parts of Penthorum chinense
}

\section{Pisey Pel}

Seoul National University College of Pharmacy

Hee-Sung Chae

Seoul National University College of Pharmacy

Jinwoo Cho

Seoul National University College of Pharmacy

Young-Mi Kim

Seoul National University College of Pharmacy

Jungmoo Huh

Seoul National University College of Pharmacy

\section{Young Hee Choi}

Dongguk University - Seoul Campus: Dongguk University

Jinwoong Kim

Seoul National University College of Pharmacy

\section{Young-Won Chin ( $\nabla$ ywchin@snu.ac.kr)}

Seoul National University College of Pharmacy

https://orcid.org/0000-0001-6964-1779

\section{Research}

Keywords: Phethorum chinense, PCSK9, LDLR, Penthorinol A, Penhthornol B, Penthorin A, methyl gallate

Posted Date: December 2nd, 2020

DOI: https://doi.org/10.21203/rs.3.rs-113818/v1

License: (c) (i) This work is licensed under a Creative Commons Attribution 4.0 International License. Read Full License 


\section{Abstract}

Background: Penthorum chinense has been used in East Asia for the treatment of cholecystitis, infectious hepatitis, and jaundice. So far there is no report regarding proprotein convertase subtilisin/kexin type 9 inhibitory constituents from this plant. The aim of the present study was to discover new active constituents with PCSK9 expression inhibitory activities from $P$. chinense

Methods: All structures were established by interpreting NMR spectroscopic data and MS data. Further experimental and calculated ECD data were used to determine the absolute configuration of the two new neolignans. To monitor the inhibitory activity on proprotein convertase subtilisin/kexin type 9 (PCSK9) mRNA expression and PCSK9-low density lipoprotein receptor (LDLR) interaction, quantitative real timePCR, Western blot analysis, and an enzyme-linked immunosorbent assay (ELISA) method by a PCSK9biotinylated-LDLR binding assay were performed.

Results: 39 compounds were isolated and identified including two new oxepine-type neolignans, penthorinols $A(1)$ and $B(2)$ and a naturally occurring chalcone, 6'-hydroxy-2'-methoxychalcone-4'-O- $\beta$-Dglucopyranoside (20). Of all tested compounds, penthorin A (4) and methyl gallate (25) were found to suppress PCSK9 mRNA expression with $\mathrm{IC}_{50}$ values of 15.56 and $11.66 \mu \mathrm{M}$, respectively. Furthermore, penthorin A (4) and methyl gallate (25) downregulated PCSK9 protein expression. However, all compounds seemed to be inactive in PCSK9-LDLR interaction.

Conclusion: In the present study, two new compounds was discovered from this plant and active constituents with PCSK9 expression inhibitory activities were suggested.

\section{Background}

Penthorum chinense Pursh. (Penthoraceae) is an herbaceous perennial plant which grows in forests, grasslands, wetlands along rivers of China [1-3], Japan [2], Korea [2, 3], and Russia [2, 3]. The whole plants of $P$. chinense have been used in China to treat various diseases including cholecystitis [4], edema [4], infectious hepatitis [1, 4], jaundice [2, 4], and its aerial parts also used as food or tea [5-7]. Previous investigations on $P$. chinense have reported the presence of flavonoids $[1,6,7]$, lignans $[2,3]$, phenylpropanoids [5, 8], steroids [6-7], and triterpenoids [2,7] as chemical constituents. In particular, extracts or individual constituents from $P$. chinense displayed therapeutic potentials for hepatic disorders such as hepatitis [5, 6], fatty liver [3, 4], and hepatocarcinoma [2]. As our ongoing project to pursue naturally occurring inhibitors on proprotein convertase subtilisin/kexin type 9 (PCSK9) [9-11], 39 compounds including two new neolignans and two naturally occurring chalcone glycosides were isolated and all isolates were evaluated for their inhibitory activities on the expression of PCSK9 which is involved in degrading low-density lipoprotein receptor (LDLR) and thereby results in inhibiting LDL uptake into cells [12-14]. In addition, PCSK9-LDLR interaction was tested for all isolated compounds.

\section{Materials And Methods}




\section{General experimental procedures}

NMR spectra were performed on Varian 400 spectrometer (Varian, CA, USA), Bruker AVANCE 600 and Bruker AVANCE 800 spectrometer (Bruker, Karlsruhe, Germany). Waters Xevo G2 Q-TOF mass spectrometer (Waters, MA, USA) was used for collecting mass spectra. FT-IR spectra were used in a ThermoFisher Scientific, Nicolet ${ }^{\text {TM }}$ iS ${ }^{\text {TM }} 5$ FT-IR spectrometer (ThermoFisher Scientific, Madison, WI, USA). UV spectra were absorbed using a Beckman Coulter, DU 730, UV/Vis spectrophotometer (Beckman Coulter $\mathrm{GmbH}$, North Rhine-Westphalia, Germany). Optical rotations were measured with a Jasco P-2000 digital polarimeter (Jasco, Tokyo, Japan). CD spectra were measured using a Chirascan plus Circular Dichroism spectrometer (APL, Surrey, UK). HPLC were used with a Gilson 321 pump and Gilson 172 Diode Array Detector (Gilson, Madison, WI, USA) and HPLC columns [250 × 10 i.d.mm, YMC column, $4 \mu \mathrm{m}]$ (YMC, Kyoto, Japan). Water was purified using a Milli-Q system (Waters Corporation, Milford, MA, USA). Column chromatography on C-18 RP silica gel (Cosmosil, Kyoto, Japan) was used. Thin layer chromatography (TLC) analysis was performed on silica gel $60 \mathrm{~F}_{254}$ plates (Merck, Darmstadt, Germany). The spots were visualized by spraying with $10 \%$ aqueous $\mathrm{H}_{2} \mathrm{SO}_{4}$.

\section{Plant material}

The aerial parts of $P$. chinense were collected at the medicinal plant garden in September 2018 (Seoul National University, Republic of Korea). The sample was identified by J. Kim (The medicinal plant garden, College of Pharmacy, Seoul National University), and a voucher specimen (SNU-2018-09) has been deposited at the herbarium in the medicinal plant garden.

\section{Extraction and isolation}

The dried aerial parts of $P$. chinense $(1.2 \mathrm{~kg})$ were extracted with $80 \% \mathrm{MeOH}$ ( $10 \mathrm{~L}$ for $2 \mathrm{~h}, 3$ times) by sonication. The total extract was condensed in vaccuo to obtain a residue (360 g). This residue was suspended in water and partitioned with $n$-hexane $(4.1 \mathrm{~g}), n-\mathrm{BuOH}(48.22 \mathrm{~g})$ and water. The $n$-BuOH fraction (48.22 g) was subjected to a Diaion HP-20 resin column chromatography eluting with a gradient of $\mathrm{MeOH}: \mathrm{H}_{2} \mathrm{O}(0: 100,25: 75,50: 50,75: 25,100: 0)$ to give five sub-fractions (PC-1, PC-2, PC-3, PC-4 and PC$5)$.

PC-2 (15.3 g) was chromatographed by a MPLC with a reversed-phase (RP)- $\mathrm{C}_{18}$ silica gel column chromatography $(100 \mathrm{~g})$ using a gradient mixture of $\mathrm{MeOH}-\mathrm{H}_{2} \mathrm{O}(0: 100 \rightarrow 70: 30)$, resulting in 6 subfractions (PC-2A to PC-2F). PC-2B $(71.9 \mathrm{mg})$ was further purified by HPLC $(250 \times 10 \mathrm{~mm}$, YMC-pack Ph column, S-5 $\mu \mathrm{m}$ ) with an isocratic elution $(3 \mathrm{~mL} / \mathrm{min})$ of $\mathrm{MeCN}-\mathrm{H}_{2} \mathrm{O}(40: 60)$ for $10 \mathrm{~min}$, yielding $23\left(t_{\mathrm{R}}\right.$ $4.56 \mathrm{~min}, 7.6 \mathrm{mg})$ and $24\left(t_{\mathrm{R}} 8.06 \mathrm{~min}, 15.1 \mathrm{mg}\right)$. PC-2C $(80.6 \mathrm{mg})$ was purified by HPLC $(250 \times 10 \mathrm{~mm}$, YMC column, $4 \mu \mathrm{m})$ with a gradient elution $(3 \mathrm{~mL} / \mathrm{min})$ of $\mathrm{MeCN}-\mathrm{H}_{2} \mathrm{O}(20: 80 \rightarrow 100: 0)$ for $25 \mathrm{~min}$, affording $6\left(t_{\mathrm{R}} 15.72 \mathrm{~min}, 16.9 \mathrm{mg}\right), 7\left(t_{\mathrm{R}} 20.82 \mathrm{~min}, 11.7 \mathrm{mg}\right)$, and $22\left(t_{\mathrm{R}} 31.12 \mathrm{~min}, 2.8 \mathrm{mg}\right)$. PC-2D $(185.2 \mathrm{mg})$ was also separated by HPLC $(250 \times 10$ i.d. mm, YMC-pack Ph column, S-5 $\mu \mathrm{m})$ with an 
isocratic elution ( $3 \mathrm{~mL} / \mathrm{min})$ of $\mathrm{MeCN}-\mathrm{H}_{2} \mathrm{O}(15: 85)$ for $20 \mathrm{~min}$, producing $11\left(t_{\mathrm{R}} 9.83 \mathrm{~min}, 39.5 \mathrm{mg}\right), 12\left(t_{\mathrm{R}}\right.$ $13.69 \mathrm{~min}, 14.3 \mathrm{mg})$ and 25 ( $\left.t_{\mathrm{R}} 19.11 \mathrm{~min}, 19.5 \mathrm{mg}\right)$.

PC-3 (8.5 g) was chromatographed over a MPLC with a reversed-phase (RP)- $\mathrm{C}_{18}$ silica gel column chromatography $(100 \mathrm{~g})$ using a gradient mixture of $\mathrm{MeOH}-\mathrm{H}_{2} \mathrm{O}(10: 90 \rightarrow 40: 60)$, giving 17 fractions (PC$3 \mathrm{~A}$ to PC-3R). PC-3K (112.3 mg) was purified by HPLC $(250 \times 10 \mathrm{~mm}$, YMC-pack Ph column, S-5 $\mu \mathrm{m})$ with a gradient elution $(3 \mathrm{~mL} / \mathrm{min})$ of $\mathrm{MeCN}-\mathrm{H}_{2} \mathrm{O}(20: 80 \rightarrow 50: 50)$ for $15 \mathrm{~min}$, yielding $14\left(t_{\mathrm{R}} 14.76 \mathrm{~min}\right.$, $4.4 \mathrm{mg})$. From PC-3M (221.5 mg), $13\left(t_{\mathrm{R}} 14.20 \mathrm{~min}, 20.5 \mathrm{mg}\right), 10\left(t_{\mathrm{R}} 13.69 \mathrm{~min}, 14.3 \mathrm{mg}\right)$ and $27\left(t_{\mathrm{R}}\right.$ $19.11 \mathrm{~min}, 19.5 \mathrm{mg})$ were isolated by a HPLC $(250 \times 10 \mathrm{~mm}$, YMC-pack Ph column, S-5 $\mu \mathrm{m})$ with a gradient elution ( $3 \mathrm{~mL} / \mathrm{min})$ of $\mathrm{MeCN}-\mathrm{H}_{2} \mathrm{O}(20: 80 \rightarrow 40: 60)$ for $20 \mathrm{~min}$. PC-3P (101.3 mg) was also subjected to HPLC $(250 \times 10 \mathrm{~mm}$, YMC-pack Ph column, S-5 $\mu \mathrm{m})$ separation with a gradient elution $(3 \mathrm{~mL} / \mathrm{min})$ of $\mathrm{MeCN}-\mathrm{H}_{2} \mathrm{O}(20: 80 \rightarrow 50: 50)$ for $40 \mathrm{~min}$, providing $34\left(t_{\mathrm{R}} 20.64 \mathrm{~min}, 3.0 \mathrm{mg}\right)$ and $\mathbf{3 5}\left(t_{\mathrm{R}}\right.$ $33.58 \mathrm{~min}, 7.3 \mathrm{mg})$.

PC-4 (12.53 g) was fractionated by a MPLC with a reversed-phase (RP)- $\mathrm{C}_{18}$ silica gel column chromatography $(100 \mathrm{~g})$ using a gradient mixture of $\mathrm{MeOH}-\mathrm{H}_{2} \mathrm{O}(10: 90 \rightarrow 90: 10)$ into eight sub-fractions (PC-4A to PC-4H). The separation of PC-4A (13. $4 \mathrm{mg})$ using a HPLC $(250 \times 10 \mathrm{~mm}$, YMC-pack Ph column, S-5 $\mu \mathrm{m})$ with an isocratic elution $(3 \mathrm{~mL} / \mathrm{min})$ of $\mathrm{MeCN}-\mathrm{H}_{2} \mathrm{O}(20: 80)$ for $20 \mathrm{~min}$, furnishing $20\left(t_{\mathrm{R}}\right.$ $18.56 \mathrm{~min}, 0.7 \mathrm{mg})$. PC-4B $(1.78 \mathrm{~g})$ was fractionated again by a MPLC with a reversed-phase (RP)- $\mathrm{C}_{18}$ silica gel column chromatography $(50 \mathrm{~g})$ using a gradient mixture of $\mathrm{MeOH}-\mathrm{H}_{2} \mathrm{O}(10: 90 \rightarrow 90: 10)$, giving three sub-fractions (PC-4B1 to PC-4B3), including $32(10.0 \mathrm{mg})$. By using a HPLC $(250 \times 10$ i.d. mm, YMCpack Ph column, S-5 $\mu \mathrm{m}$ ) with an isocratic elution (3 mL/min) of $\mathrm{MeCN}-\mathrm{H}_{2} \mathrm{O}(20: 80)$ for $30 \mathrm{~min}, 37\left(t_{\mathrm{R}}\right.$ $25.59 \mathrm{~min}, 8.8 \mathrm{mg}), 33\left(t_{\mathrm{R}} 27.78 \mathrm{~min}, 15.4 \mathrm{mg}\right)$ and $\mathbf{3 6}\left(t_{\mathrm{R}} 30.62 \mathrm{~min}, 9.9 \mathrm{mg}\right)$ was isolated from PC-4B3 (213.9 mg). The separation for PC-4C (12.3 mg) by a HPLC $(250 \times 10 \mathrm{~mm}$, YMC-pack Ph column, S-5 $\mu \mathrm{m})$ with an isocratic elution ( $3 \mathrm{~mL} / \mathrm{min})$ of $\mathrm{MeCN}-\mathrm{H}_{2} \mathrm{O}(20: 80)$ for $16 \mathrm{~min}$ afforded 39 ( $\left.t_{\mathrm{R}} 15.34 \mathrm{~min}, 4.0 \mathrm{mg}\right)$. PC-4D $(213.9 \mathrm{mg})$ was purified by a HPLC $(250 \times 10 \mathrm{~mm}$, YMC-pack Ph column, S- $5 \mu \mathrm{m})$ with a gradient elution $(3 \mathrm{~mL} / \mathrm{min})$ of $\mathrm{MeCN}-\mathrm{H}_{2} \mathrm{O}(10: 90 \rightarrow 50: 50)$ for $20 \mathrm{~min}$, yielding $38\left(t_{\mathrm{R}} 14.05 \mathrm{~min}, 5.1 \mathrm{mg}\right)$. PC-4E $(94.1 \mathrm{mg})$ was applied to a HPLC $(250 \times 10$ i.d. mm, YMC-pack Ph column, S-5 $\mu \mathrm{m})$ separation with an isocratic elution ( $3 \mathrm{~mL} / \mathrm{min}$ ) of $\mathrm{MeCN}-\mathrm{H}_{2} \mathrm{O}(30: 70)$ for $22 \mathrm{~min}$, furnishing $26\left(t_{\mathrm{R}} 19.72 \mathrm{~min}, 1.6 \mathrm{mg}\right)$ and 21 ( $t_{\mathrm{R}} 20.13 \mathrm{~min}, 1.3 \mathrm{mg}$ ). PC-4F (2.14 g) was subjected to a Sephadex LH-20 column chromatography eluted using $100 \% \mathrm{MeOH}$, giving four sub-fractions (PC-4F1 to PC-4F4). PC-4F1 (201.3 mg) was separated by HPLC $(250 \times 10 \mathrm{~mm}$, YMC-pack Ph column, S- $5 \mu \mathrm{m})$ with an isocratic elution $(3 \mathrm{~mL} / \mathrm{min})$ of $\mathrm{MeCN}-\mathrm{H}_{2} \mathrm{O}$ (35:65) for $25 \mathrm{~min}$, providing $16\left(t_{\mathrm{R}} 23.66 \mathrm{~min}, 44.0 \mathrm{mg}\right)$. The same separation method was applied to the fractions PC-4F2 (44.2 mg) and PC-4F3 $(52.6 \mathrm{mg})$, giving $29\left(t_{\mathrm{R}} 18.78 \mathrm{~min}, 15.0 \mathrm{mg}\right)$ and 28 $\left(t_{\mathrm{R}} 20.46 \mathrm{~min}, 1.0 \mathrm{mg}\right)$, respectively. PC-4G $(1.2 \mathrm{~g})$ was subjected to a Sephadex LH-20 column chromatography eluted with $100 \% \mathrm{MeOH}$, providing four sub-fractions (PC-4G1 to PC-4G4), including pure 15 (0.6 mg). PC-4G2 (243.1 mg) and PC-4G3 (45.9 mg) were isolated using HPLC $(250 \times 10$ i.d. mm, YMCpack Ph column, S-5 $\mu \mathrm{m}$ ) with an isocratic elution ( $3 \mathrm{~mL} / \mathrm{min}$ ) of $\mathrm{MeCN}-\mathrm{H}_{2} \mathrm{O}(40: 60)$ for $20 \mathrm{~min}$, affording $18\left(t_{R} 16.2 \mathrm{~min}, 160.0 \mathrm{mg}\right)$ and $17\left(t_{R} 19.61 \mathrm{~min}, 9.4 \mathrm{mg}\right)$, respectively. PC-4G4 (214.6 mg) was 
purified by a HPLC $(250 \times 10 \mathrm{~mm}$, YMC-pack Ph column, S-5 $\mu \mathrm{m})$ with an isocratic elution $(3 \mathrm{~mL} / \mathrm{min})$ of $\mathrm{MeCN}-\mathrm{H}_{2} \mathrm{O}(55: 45)$ for $20 \mathrm{~min}$, yielding $30\left(t_{\mathrm{R}} 14.23 \mathrm{~min}, 19.4 \mathrm{mg}\right)$ and $31\left(t_{\mathrm{R}} 18.26 \mathrm{~min}, 6.4 \mathrm{mg}\right)$. The fraction PC-4H (312.8 mg) was subjected to a Sephadex LH-20 column chromatography eluted with $100 \% \mathrm{MeOH}$, fractionated into two sub-fractions (PC-4H1 to PC-4H2). From PC-4H1 (54.1 mg), 19 ( $t_{\mathrm{R}}$ $14.23 \mathrm{~min}, 4.4 \mathrm{mg})$ was purified by a HPLC $(250 \times 10 \mathrm{~mm}$, YMC-pack Ph column, S-5 $\mu \mathrm{m})$ separation with an isocratic elution ( $3 \mathrm{~mL} / \mathrm{min})$ of $\mathrm{MeCN}-\mathrm{H}_{2} \mathrm{O}(55: 45)$ for $15 \mathrm{~min}$.

PC-5 (4.5 g) was chromatographed on a silica gel column using gradient mixtures of $n$-hexane-EtOAC (10:1 to 1:1) and then chloroform-MeOH (10:1 to 1:1), producing nine sub-fractions (PC-5A to PC-5J). PC5A (20.4 mg) was purified by a HPLC $(250 \times 10$ i.d. mm, YMC-pack Ph column, S-5 $\mu \mathrm{m})$ with a gradient elution $(3 \mathrm{~mL} / \mathrm{min})$ of $\mathrm{MeCN}-\mathrm{H}_{2} \mathrm{O}(50: 50 \rightarrow 100: 0)$ for $40 \mathrm{~min}$, affording $9\left(t_{\mathrm{R}} 24.35 \mathrm{~min}, 6.6 \mathrm{mg}\right)$ and $\mathbf{1}\left(t_{\mathrm{R}}\right.$ $31.85 \mathrm{~min}, 3.8 \mathrm{mg})$. The separation of PC-5B $(18.2 \mathrm{mg})$ using a HPLC $(250 \times 10$ i.d. mm, YMC-pack Ph column, S-5 $\mu \mathrm{m})$ with a gradient elution $(3 \mathrm{~mL} / \mathrm{min})$ of $\mathrm{MeCN}-\mathrm{H}_{2} \mathrm{O}(10: 90 \rightarrow 100: 0)$ for 40 min furnished 2 $\left(t_{\mathrm{R}} 27.56 \mathrm{~min}, 4.4 \mathrm{mg}\right)$ and $8\left(t_{\mathrm{R}} 28.96 \mathrm{~min}, 1.7 \mathrm{mg}\right)$. From PC-5E (22.0 mg), $3\left(t_{\mathrm{R}} 35.12 \mathrm{~min}, 1.0 \mathrm{mg}\right), \mathbf{5}\left(t_{\mathrm{R}}\right.$ $37.19 \mathrm{~min}, 0.8 \mathrm{mg})$ and $4\left(t_{\mathrm{R}} 41.23 \mathrm{~min}, 1.7 \mathrm{mg}\right)$ were isolated by a HPLC $(250 \times 10$ i.d. mm, YMC-pack Ph column, S-5 $\mu \mathrm{m})$ with a gradient elution $(3 \mathrm{~mL} / \mathrm{min})$ of $\mathrm{MeCN}-\mathrm{H}_{2} \mathrm{O}(20: 80 \rightarrow 50: 50)$ for $40 \mathrm{~min}$.

Penthorinol A (1): Brown amorphous powder, $[\mathrm{a}]_{\mathrm{D}}^{20}=-18.11(c 0.08, \mathrm{MeOH}) ; \mathrm{UV}(\mathrm{MeOH}) \lambda_{\max }(\log \varepsilon)$ : 212.5 (4.41); ECD (MeOH) $\lambda_{\max } 251$ (-3.54), 317 (1.88);. FT-IR (ATR) $v_{\max } 3416,2929,1713,1611$, $1231 \mathrm{~cm}^{-1}$; HRESIMS $\mathrm{m} / \mathrm{z}[\mathrm{M}+\mathrm{H}]^{+} 327.1232$ (calcd for $\mathrm{C}_{19} \mathrm{H}_{19} \mathrm{O}_{5} 327.1232$ ).

Penthorinol B (2): Brown amorphous powder, $[\mathrm{a}]_{\mathrm{D}}{ }^{20}=-50.50\left(\right.$ c 0.44, MeOH); UV (MeOH) $\lambda_{\max }(\log \varepsilon)$ : 215.5 (4.27); ECD (MeOH) $\lambda_{\max } 232$ (-2.06), 324 (0.64); FT-IR (ATR) $v_{\max } 3431,2932,1660,1603$, $1212 \mathrm{~cm}^{-1}$; HRESIMS $\mathrm{m} / \mathrm{z}[\mathrm{M}+\mathrm{H}]^{+} 327.1235$ (calcd for $\mathrm{C}_{19} \mathrm{H}_{19} \mathrm{O}_{5} 327.1232$ ).

6'-hydroxy-2'-methoxychalcone-4'-O- $\beta$-D-glucopyranoside (20): Yellowish powder, $[\mathrm{a}]_{D}^{20}=-78.4(c 0.10$, $\mathrm{MeOH}) ; \mathrm{UV}(\mathrm{MeOH}) \lambda_{\max }(\log \varepsilon): 330$ (3.14), 205 (3.35). ${ }^{1} \mathrm{H}-\mathrm{NMR}\left(\mathrm{CD}_{3} \mathrm{OD}, 800 \mathrm{MHz}\right): \delta_{\mathrm{H}} 7.89(1 \mathrm{H}, \mathrm{d}, J=$ $15.6 \mathrm{~Hz}, \mathrm{H}-\beta), 7.73(1 \mathrm{H}, \mathrm{d}, J=15.6 \mathrm{~Hz}, \mathrm{H}-\mathrm{a}), 7.66(1 \mathrm{H}, \mathrm{d}, J=15.6 \mathrm{~Hz}, \mathrm{H}-2$ and 6$), 7.41(3 \mathrm{H}, \mathrm{m}, \mathrm{H}-3,4$, and 5), $6.34\left(1 \mathrm{H}, \mathrm{d}, J=2.2 \mathrm{~Hz} \mathrm{H}-3^{\prime}\right), 6.26\left(1 \mathrm{H}, \mathrm{d}, J=2.2 \mathrm{~Hz}, \mathrm{H}-5^{\prime}\right), 5.01\left(1 \mathrm{H}, \mathrm{d}, J=7.3 \mathrm{~Hz}, \mathrm{H}-1{ }^{\prime \prime}\right), 3.92(1 \mathrm{H}, \mathrm{dd}, J=$ 12.2, $2.2 \mathrm{~Hz}, \mathrm{H}-6 \mathrm{~b} "), 3.70$ (1H, dd, $J=12.2,2.2 \mathrm{~Hz}, \mathrm{H}-6 \mathrm{~b} "), 3.51$ (H, m, H-3" and 5"), $3.47(\mathrm{H}, \mathrm{m}, \mathrm{H}-2 "), 3.38$ $\left(\mathrm{H}, \mathrm{m}, \mathrm{H}-4^{\prime \prime}\right)$, and $3.97\left(3 \mathrm{H}, \mathrm{s}, 2^{\prime}-\mathrm{OCH} 3\right) .{ }^{13} \mathrm{C}-\mathrm{NMR}\left(\mathrm{CD}_{3} \mathrm{OD}, 200 \mathrm{MHz}\right): \delta_{\mathrm{C}} 194.6$ (C-7'), $167.8\left(\mathrm{C}-6^{\prime}\right), 165.4$ (C4'), 164.1 (C-2'), 143.7 (C-a), 136.7 (C-1), 131.3 (C-4), 130.0 (C-3 and 5), 129.4 (C- 2 and 6), 108.4 (C-1'), 101.4 (C-1"), 98.0 (C-5'), 93.2 (C-3'), 78.5 (C-5"), 77.9 (C-3"), 74.7 (C-2"), 71.3 (C-4"), 62.5 (C-6"), and 62.5 (2'$\mathrm{OCH}_{3}$ ). HRESIMS $\mathrm{m} / \mathrm{z}[\mathrm{M}-\mathrm{H}]^{-} 431.1346$ (calcd for $\mathrm{C}_{22} \mathrm{H}_{23} \mathrm{O}_{9} 431.1342$ ).

\section{Calculated ECD prediction}


The structures (1 and 2) were generated using ChemBio3D Ultra 13.03 and then summited in Spartan 16 program searched for conformational using with MMFF94 force filed minimization. All 13 conformers which had Boltzmann-averaged weight less than 0.95 were selected and optimized using theoretical method of density functional theory (B3LYP) and a basis set of 6-31+G (d,p) in Gaussian 16 software (Gaussian Inc., Wallingford, CT, USA) in gas phase. Finally, their calculated ECD was carried out using TDDFT with the CAM-B3LYP/6-31 + G (d,p) method and the methanol-selected CPCM in Gaussian 16 software $[15,16]$. Lastly, the calculated ECD curves of possible structures (1a and $\mathbf{1 b})$ were compared with the experimental ECD curves (Fig. S23 (A) and 23 (B), Supporting Information). The ECD spectra were plotted using SpecDis v. 1.71 software and applying a Gaussian band shape with a sigma/gamma value of $0.20 \mathrm{eV}$ to simulate the experimental curve (Fig. S23 (C), Supporting Information). The predicted ECD spectrum was obtained using a Boltzmann population-weighted average and was plotted with Gnuplot v. 5.2.

\section{Sugar analysis of compound 20}

The sugars such d-galactose and d-/L-glucose were prepared $2.0 \mathrm{mg}$ respectively for each. I-cysteine methyl ester and isothiocyanate were dissolved with pyridine in concentration $5 \mathrm{mg} / \mathrm{mL}$ in individually. Compound $20\left(0.3 \mathrm{mg}\right.$, respectively) was dissolved in $10 \% \mathrm{HCl}(2 \mathrm{~mL})$ and heated in water bath at $90{ }^{\circ} \mathrm{C}$ for two hours. After heating, the solution was dried using a stream of $\mathrm{N}_{2}$. The compound crudes and each sugar (2 mg) was added $200 \mu \mathrm{L}$ of I-cysteine methyl ester and pyridine solution and heat $60^{\circ} \mathrm{C}$ for an hour and then added $200 \mu \mathrm{L}$ of isothiocyanate and pyridine solutions and heat $60{ }^{\circ} \mathrm{C}$ for an hour as well. Finally, all solutions were filter and subjected in HPLC, using the YMC-Pack-ODS-A column $(250 \times 4.6 \mathrm{~mm}$, $5 \mu \mathrm{m}$ ) with $\mathrm{MeCN}-\mathrm{H}_{2} \mathrm{O}(20: 80), 0.8 \mathrm{~mL} / \mathrm{min}$, by isocratic for $35 \mathrm{~min}$ and the MeCN 100\% for 5 min with detector wavelength was $250 \mathrm{~nm}$. The absolute configuration of sugars in each compound was established by comparison of the retention times with those of the authentic sugar $[17,18]$ (Fig. S30).

\section{Immunoblot Analysis}

Protein expression was assessed by Western blotting according to standard procedures. ${ }^{17}$ Images were acquired using a ChemiDoc Imaging system (ChemiDoc ${ }^{T M}$ XRS system with Image Lab ${ }^{\text {TM }}$ software 3.0; BioRad, Hercules, CA, USA).

\section{Quantitative real-time RT-PCR}

Total cellular RNA was isolated using a Trizol RNA extraction kit according to the manufacturer's instructions. Briefly, total RNA $(1 \mu g)$ was converted to cDNA by treatment with 200 units reverse transcriptase and $500 \mathrm{ng}$ oligo-dT primers in $50 \mathrm{mM}$ Tris- $\mathrm{HCl}(\mathrm{pH} 8.3), 75 \mathrm{mM} \mathrm{KCl}, 3 \mathrm{mM} \mathrm{MgCl} 2,10 \mathrm{mM}$ dithiothreitol, and $1 \mathrm{mM}$ dNTPs at $42{ }^{\circ} \mathrm{C}$ for $1 \mathrm{~h}$. The reaction was stopped by incubating the solution at $70^{\circ} \mathrm{C}$ for $15 \mathrm{~min}$, after which $1 \mu \mathrm{L} \mathrm{cDNA}$ mixture was used for enzymatic amplification. PCR reactions were performed using $1 \mu \mathrm{L} \mathrm{cDNA}$ and $9 \mu \mathrm{L}$ master mix containing iQ SYBR Green Supermix (Bio-Rad), 5 pmol of forward primer, and 5 pmol reverse primer, in a CFX384 Real-Time PCR Detection System (BioRad). The reaction conditions were $3 \mathrm{~min}$ at $95^{\circ} \mathrm{C}$ followed by 40 cycles of $10 \mathrm{~s}$ at $95^{\circ} \mathrm{C}$ and $30 \mathrm{~s}$ at 55 ${ }^{\circ} \mathrm{C}$. The plate was subsequently read. The fluorescence signal generated with SYBR Green I DNA dye was 
measured during the annealing steps. The specificity of the amplification was confirmed using a melting curve analysis. Data were collected and recorded by CFX Manager Software (Bio-Rad) and expressed as a function of the threshold cycle $\left(\mathrm{C}_{\mathrm{T}}\right)$. The relative quantity of the gene of interest was then normalized to the relative quantity of GAPDH $(\triangle \triangle C T)$. The mRNA abundance in the sample was calculated using the Eq. $2^{-(\triangle \triangle C T)}$. The following specific primer sets were used (5' to $\left.3^{\prime}\right)$ : human - GAPDH:

GAAGGTGAAGGTCGGAGTCA (forward), AATGAAGGGGTCATTGATGG (reverse); human - PCSK9: GGTACTGACCCCCAACCTG (forward), CCGAGTGTGCTGACCATACA (reverse); Gene-specific primers were custom-synthesized by Bioneer.

\section{PCSK9-LDLR binding assay}

All the isolated compounds were evaluated using an enzyme-linked immunosorbent assay (ELISA) method by a PCSK9-biotinylated-LDLR binding assay kit (BPS Bioscience, Inc., San Diego, USA; cat no. \#72002) according to the manufacturer's protocol. A positive control, alirocumab (TAB-719) was purchased from Creative Biolabs (Shirley, NY, USA).

\section{Statistical Analysis}

For multiple comparisons, one-way analysis of variance (ANOVA) was performed followed by Dunnett's ttest. Data from experiments are presented as means \pm standard error of the mean (SEM). The number of independent experiments analyzed is given in the figure captions.

\section{Results}

Isolation and structure elucidation of chemical constituents from P. chinense

Isolation work for the $\mathrm{BuOH}-$ soluble extract of $80 \%$ methanol extract of $P$. chinense led to the isolation and identification of 39 compounds including two new compounds. The 37 known structures (3-39) were established by comparison of their measured spectroscopic data with the literatures as ( $7^{\prime} E$, 8S)-2',4,8-trihydroxy-3-methoxy-2,4'-epoxy-8,5'-neolign-7'-en-7-one (3) [19], penthorin A (4) [20], penchinone $C$ (5) [21], phyllanemblinin $F(6)$ [1], penthorumin $C$ (7) [3], pinocembrin (8) [22], (S)-3-hydroxy-3-phenylpropanoic acid (9) [23], 7-O-galloylcatechin (10) [24], 1,6-di-O-galloyl- $\beta$-D-glucose (11) [25], strictinin (12) [26], 1,2,3,6-tetra-O-galloyl- $\beta$-D-glucose (13) [25], 1,2,6-tri-O-galloyl- $\beta$-D-glucose (14) [27], 6'-hydroxy-2'methoxy-dihydrochalcone-4'-O- $\beta$-D-glucopyranoside (15) [28], 2' ,6' -dihydroxydihydrochalcone-4'-O- $\beta$-Dglucopyranoside (16) [6], 2',6'-dihydroxy-4'-O-(6-O-galloyl- $\beta$-D-glucopyranosyl)dihydrochalcone (17) [29], thonningianin $B(18)$ [3], thonningianin A (19) [3], 6'-hydroxy-2'-methoxychalcone-4'-O- $\beta$-Dglucopyranoside (20) [30], deoxyphloridzin (21) [31], 4-hydroxybezoic acid (22) [10], 1-O-galloyl- $\beta$-Dglucopyranose (23) [32], gallic acid (24) [10], methyl gallate (25) [33], 2,6-dihydroxyacetophenone-4-O- $\beta$-Dglucoside (26) [7], 2,6-dihydroxyacetophenone-4-O-[4区,6囚-(S)-hexahydroxydiphenoyl]- $\beta$-D-glucose (27) [3],

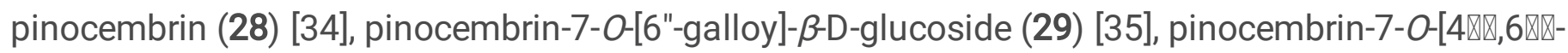

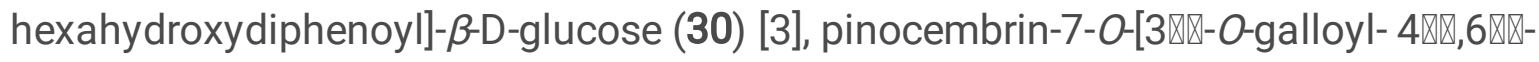
hexahydroxydiphenoyl]- $\beta$-D-glucose (31) [3], avicularoside (32) [36], afzelin (33) [37], quercitrin (34) [37], 
quercetin (35) [10], kaempferol (36) [10], astragalin (37) [38], isoquercitrin (38) [38], ellagic acid (39) [39] (Fig. 1).

Compound 1 was obtained as brown amorphous solid, and its molecular formula was determined to be $\mathrm{C}_{19} \mathrm{H}_{18} \mathrm{O}_{5}$ by a protonated molecule $[\mathrm{M}+\mathrm{H}]^{+}$at $\mathrm{m} / z 327.1232$ in the HRESIMS. The ${ }^{1} \mathrm{H}-\mathrm{NMR}$ spectroscopic data (Table 1) of 1 displayed the signals for two aromatic protons assignable to an 1,2,3,4tetrasubstituted benzene ring at $\delta_{\mathrm{H}} 7.75(1 \mathrm{H}, \mathrm{d}, J=8.9 \mathrm{~Hz}, \mathrm{H}-6), 6.75(1 \mathrm{H}, \mathrm{d}, J=8.9 \mathrm{~Hz}, \mathrm{H}-5)$, the signals for three aromatic protons assignable to an 1,3,4-trisubstituted benzene ring at $\delta_{\mathrm{H}} 7.73(1 \mathrm{H}, \mathrm{d}, J=2.2 \mathrm{~Hz}, \mathrm{H}$ $\left.2^{\prime}\right), 7.32\left(1 \mathrm{H}, \mathrm{dd}, J=8.1,2.2 \mathrm{~Hz}, \mathrm{H}-6^{\prime}\right), 7.26\left(1 \mathrm{H}, \mathrm{d}, J=8.1 \mathrm{~Hz}, \mathrm{H}-5^{\prime}\right)$, the signals of a propenyl group $(\mathrm{CH}=$ $\left.\mathrm{CH}^{-\mathrm{CH}_{3}}\right)$ at $\delta_{\mathrm{H}} 6.42\left(1 \mathrm{H}, \mathrm{dd}, J=15.7,1.4 \mathrm{~Hz}, \mathrm{H}-7^{\prime}\right), 6.28\left(1 \mathrm{H}, \mathrm{m}, \mathrm{H}-8^{\prime}\right)$, and $1.87\left(3 \mathrm{H}, \mathrm{dd}, J=6.6,1.4 \mathrm{~Hz}, \mathrm{H}-9^{\prime}\right)$, the signal of a methyl proton at $\delta_{\mathrm{H}} 1.66(1 \mathrm{H}, \mathrm{s}, \mathrm{H}-9)$, and the signal of a methoxy group at $\delta_{\mathrm{H}} 3.99(3 \mathrm{H}, \mathrm{s}$, $\left.3-\mathrm{OCH}_{3}\right)$, suggesting that compound 1 is structurally similar to $(7 \mathrm{E})$-2',4,8-trihydroxy-3-methoxy-2,4'epoxy-8,5'-neolign-7'-en-7-one (3) [19] except for the absence of one hydroxy group in 1 . The propenyl group was attached to the 1,3,4-trisubstituted benzene ring by the observed $\mathrm{HMBC}$ correlations (Fig. 2A) of $\delta_{\mathrm{H}} 6.42\left(\mathrm{H}-7^{\prime}\right)$ to $\delta_{\mathrm{C}} 137.6\left(\mathrm{C}-1^{\prime}\right), 127.5\left(\mathrm{C}-6^{\prime}\right)$ and $124.6\left(\mathrm{C}-2^{\prime}\right)$ and sequential correlations of $\mathrm{H}-5^{\prime} / \mathrm{H}-6^{\prime}$, and $\mathrm{H}-7^{1} / \mathrm{H}-8 / / \mathrm{H}-9$ in the ${ }^{1} \mathrm{H}^{-1} \mathrm{H}$ COSY spectrum. In addition, the $\mathrm{HMBC}$ correlations of $\delta_{\mathrm{H}} 7.75(\mathrm{H}-6)$ to $\delta_{\mathrm{C}}$ 194.5 (C-7), 158.4 (C-4), 154.3 (C-2) and 116.7 (C-1), $\delta_{\mathrm{H}} 6.75$ (H-5) to $\delta_{\mathrm{C}} 158.4$ (C-4), 139.2 (C-3) and 116.7 $(\mathrm{C}-1), \delta_{\mathrm{H}} 1.66(\mathrm{H}-9)$ to $\delta_{\mathrm{C}} 194.5(\mathrm{C}-7)$ and $79.6(\mathrm{C}-8)$ was able to connect the 1,2,3,4-tetrasubstituted benzene ring to a 2-hyroxypropan-1-one [C7-C8-C9]. The remaining methoxy group was located on $\mathrm{C}-3$ by the observed $\mathrm{HMBC}$ correlation of $\delta_{\mathrm{H}} 3.99\left(3-\mathrm{OCH}_{3}\right)$ to $\delta_{\mathrm{C}} 139.2(\mathrm{C}-3)$. Also, $\mathrm{HMBC}$ correlations of $\delta_{\mathrm{H}} 1.66$ $(\mathrm{H}-9)$ to $\delta_{\mathrm{C}} 134.5\left(\mathrm{C}-3^{\prime}\right)$; and $\delta_{\mathrm{H}} 7.73\left(\mathrm{H}-2^{\prime}\right)$ to $\delta_{\mathrm{C}} 79.6(\mathrm{C}-8)$ as well as NOE correlations between $\mathrm{H}-5^{\prime}$ and the methoxy group in the NOESY spectrum (Fig. 2B) suggested the structure 1 to be a neolignane with a dibenzo[ $[b, f]$ oxepinone moiety as shown in Fig. 1 . To determine the absolute configuration of 1 , the experimental ECD data of 1 was compared with the ECD data of the calculated structures $(8 R) 1 \mathrm{a}$ and (8S) $1 \mathrm{~b}$, and the ECD data of $(8 S) \mathbf{1 b}$ bore close resemblance to that of 1 (Fig. 3A). Therefore, this compound was characterized as $(S, E)-7,11$-dihydroxy-6-methoxy-11-methyl-2-(prop-1-en-1yl)dibenzo[b,f]oxepin-10(11H)-one, and named penthorinol A.

The molecular formula of compound 2 was determined to be $\mathrm{C}_{19} \mathrm{H}_{18} \mathrm{O}_{5}$ by a protonated molecule $[\mathrm{M}+\mathrm{H}]^{+}$ at $m / z 327.1235$ in the HRESIMS. The ${ }^{1} \mathrm{H}-\mathrm{NMR}$ and ${ }^{13} \mathrm{C}$ NMR spectroscopic data of 2 were similar to those of penthorinol A (1) except for the slight differences in ${ }^{1} \mathrm{H}$ and ${ }^{13} \mathrm{C}$ chemical shifts of $\mathrm{C}-5$ and $\mathrm{C}-6$ (Table 1). These differences were derived from the location of methoxy group on $\mathrm{C}-4$, which was supported by the observed HMBC correlations (Fig. 2A) of $\delta_{\mathrm{H}} 6.93(\mathrm{H}-5)$ to $\delta_{\mathrm{C}} 154.9(\mathrm{C}-4), 138.2(\mathrm{C}-3)$ and $117.9(\mathrm{C}-1), \delta_{\mathrm{H}} 7.64(\mathrm{H}-6)$ to $\delta_{\mathrm{C}} 195.2(\mathrm{C}-7), 154.9(\mathrm{C}-4), 148.1(\mathrm{C}-2), 117.9(\mathrm{C}-1)$ and $108.5(\mathrm{C}-5)$, and $\delta_{\mathrm{H}}$ $3.96\left(\mathrm{OCH}_{3}\right)$ to $\delta_{\mathrm{C}} 154.9(\mathrm{C}-4)$, as well as NOE correlation between $\mathrm{H}-5$ and the methoxy group, positioning the methoxy group on C-4 (Fig. 2B). The absolute configuration of 2 was determined to be $S$ by comparing the measured ECD data of $\mathbf{2}$ with those of compounds 1 and $\mathbf{3}$, showing similar ECD curves (Fig. 3B). Therefore, this compound was characterized as (S,E)-6,11-dihydroxy-7-methoxy-11-methyl-2(prop-1-en-1-yl)dibenzo[ $[b, f]$ oxepin-10(11H)-one and named penthorinol B. 
Table 1

${ }^{1} \mathrm{H}$ and ${ }^{13} \mathrm{C}$ NMR Data of 1 and 2 in methanol- $d_{4}$

\begin{tabular}{|c|c|c|c|c|}
\hline & 1 & 2 & & \\
\hline Position & $\delta_{\mathrm{H}}$ & $\delta_{\mathrm{C}}$ & $\delta_{\mathrm{H}}$ & $\delta_{\mathrm{C}}$ \\
\hline 1 & - & 116.7 & - & 117.9 \\
\hline 2 & - & 154.3 & - & 148.1 \\
\hline 3 & - & 139.2 & - & 138.2 \\
\hline 4 & - & 158.4 & - & 154.9 \\
\hline 5 & $6.75, d(8.9)$ & 113.4 & $6.93, d(8.9)$ & 108.5 \\
\hline 6 & 7.75, d (8.9) & 128.2 & $7.64, d(8.9)$ & 123.2 \\
\hline 7 & - & 194.6 & - & 195.2 \\
\hline 8 & - & 79.6 & - & 79.9 \\
\hline 9 & $1.66, s$ & 24.5 & $1.69, \mathrm{~s}$ & 24.5 \\
\hline $1^{\prime}$ & - & 137.6 & - & 137.4 \\
\hline $2^{\prime}$ & $7.73, d(2.2)$ & 124.6 & $7.72, d(2.1)$ & 124.5 \\
\hline $3^{\prime}$ & - & 134.5 & - & 134.7 \\
\hline $4^{\prime}$ & - & 153.7 & - & 154.2 \\
\hline $5^{\prime}$ & 7.26, d (8.1) & 122.2 & $7.33, d(8.3)$ & 122.8 \\
\hline $6^{\prime}$ & $7.32, \mathrm{dd}(8.1,2.2)$ & 127.6 & 7.30, dd $(8.3,2.1)$ & 127.6 \\
\hline $7^{\prime}$ & $6.42, \mathrm{dd}(15.7,1.4)$ & 131.3 & $6.43, \mathrm{dd}(15.7,1.4)$ & 131.5 \\
\hline $8^{\prime}$ & $6.28, \mathrm{~m}$ & 127.2 & 6.27, m & 127.1 \\
\hline $9^{\prime}$ & 1.87, dd $(6.6,1.4)$ & 18.6 & $1.87, \mathrm{dd}(6.6,1.5)$ & 18.7 \\
\hline $3-\mathrm{OCH}_{3}$ & $3.99, \mathrm{~s}$ & 62.2 & - & - \\
\hline $4-\mathrm{OCH}_{3}$ & - & - & $3.96, \mathrm{~s}$ & 57.0 \\
\hline
\end{tabular}

\section{PCSK9 inhibitory activities of isolated compounds}

All the compounds 1-39 were tested in PCSK9 mRNA expression using HepG2 cell (Fig. 4). Of the isolates, penthorin A (4) and methyl gallate (25) were found to significantly inhibit PCSK9 mRNA 
expression with $\mathrm{IC}_{50}$ values of 15.56 and $11.66 \mu \mathrm{M}$ (Fig. $\left.5 \mathrm{~A}\right)$, respectively, in assay system $\left(\mathrm{IC}_{50}\right.$ value of positive control, berberine, $9.84 \mu \mathrm{M}$ ) while other compounds deemed inactive. In further Western blotting analysis, penthorin A (4) and methyl gallate (25) demonstrated to inhibit PCSK9 expression in HepG2 cells when compared with a positive control (berberine). In addition, all isolated compounds (1-39) were evaluated for their inhibitory activities against PCSK9-LDLR interaction. As shown in Fig. S31, all compounds were not significantly to inhibit PCSK9-LDLR interaction at a concentration of $50 \mu \mathrm{M}$.

\section{Discussion}

Phytochemical investigations on $P$. chinense have been widely documented and reviewed elsewhere [4, 5, $7,8,35]$. The oxepine-type lignans including two new compounds 1 and 2 were isolated from this plants. Of the known structures, compound 20, 6'-hydroxy-2'-methoxychalcone-4'-O- $\beta$-D-glucopyranoside, previously this compound was produced by microbial glycosylation [30] and as a naturally occurring molecule, the current study was the first report to isolate and identify this compound from natural sources. The structure of compound $\mathbf{2 0}$ was confirmed by interpreting 1D and 2D NMR spectroscopic data, and analysis of acidic hydrolysates, which was compared with the published values [30]. In the present study, three new naturally occurring compounds were identified from this plant for the first time.

PCSK9 is a gene that is involved in lipid metabolism and atherosclerosis [40]. In particular, PCSK9 protein binds to LDLR and then facilitates the degradtion of LDLR, leading to blocking the recycle of LDLR and consequently inhibiting LDL uptake from blood into hepatocyte. For this function of PCSK9, PCSK9 inhibitors are emerging as an additional lipid-lowering therapy for patients with artery disease [41]. Interestingly, a few statin drugs including atorvastatin are known to induce transcriptional expression of PCSK9, which may explain of the limitation of statin treatment in some patients $[42,43]$. So far, as PCSK9 inhibitor drugs, antibody drugs which inhibit PCSK9-LDLR binding have been launched while natural product-derived small molecules or synthetic small molecules are underway [44]. In the present study, penthorin A (4) and methyl gallate (25) were found to downregulate PCSK9 mRNA and protein expression. However, penthorin A (4) seemed to inhibit PCSK9 expression without affecting LDLR while methyl gallate (25) slightly increased LDLR protein expression (Fig. 5B), comparable to the positive control, berberine. Methyl gallate is widely distrubuted in the plant kingdom and the present finding may give more applications of specific plants with high quantity of methyl gallate in the future. Even though in the limited structures with gallic acid moiety (Fig. S1), it could be highlighted that methyl gallate (25) was important structure in modulating PCSK9 and LDLR expression.

\section{Conclusion}

In the present study, three new naturally occurring compounds $(1,2$ and 20$)$ were isolated from $P$. chinense and two compounds (4 and 25 ) were found to downregulate PCSK9 expression. Considering most PCSK9 are expressed in liver and the medicinal applications of this plant are related to hepatic disorders, these findings may help add values of this plant in the future. 


\section{Abbreviations}

P. chinense, Penthorum chinense; PCSK9, Proprotein convertase subtilisin-kexin type 9; LDL, low-density lipoprotein; HPLC, high-performance liquid chromatography; MPLC, medium-performance liquid chromatography; MeCN, acetonitrate; ECD, electronic circular dichroism; UV, ultraviolet visible; Ber, Berberine.

\section{Declarations}

\section{Acknowledgments}

Not applicable

\section{Availability of data and materials}

All the data used to support this study are available from additional file 1 (Figures of mass spectrometric data, ECD, UV, IR, and NMR spectra of 1 and 2 including ${ }^{1} \mathrm{H}$ and ${ }^{13} \mathrm{C}$ NMR spectra, NOESY spectra, and experimental ECD of $\mathbf{1}$ and $\mathbf{2}$, comparisons of experimental and calculated ECD of all new compounds).

\section{Authors' contributions}

P. P. and H.-S. C. performed the isolation works and biological works. The structures elucidation was conducted by P. P., J. W. C., Y.-M. K.; J. H., Y. H. C.; J. K., and Y.-W. C. P. P. and Y.-W. C. were major contributor in designing the research and writing the manuscript. All authors have approved for final version of the manuscript.

\#Pisey Pel, and Hee-Sung Chae contributed equally to this work.

\section{Funding}

This work was supported by grants (NRF-2019R1A2C2009053) from the National Research Foundation of Korea (NRF) funded by the Korean government (MSIT).

\section{Author information}

*Corresponding Author: Phone: +82-2-880-7859; E-mail: ywchin@snu.ac.kr

${ }^{1}$ College of Pharmacy and Research Institute of Pharmaceutical Sciences, Seoul National University, 1, Gwanak-ro, Gwanak-gu, Seoul 08826, Republic of Korea

\section{Author details}

${ }^{1}$ College of Pharmacy and Research Institute of Pharmaceutical Sciences, Seoul National University, 1 , Gwanak-ro, Gwanak-gu, Seoul 08826, Republic of Korea. 
${ }^{2}$ College of Pharmacy and Integrated Research Institute for Drug Development, Dongguk University_Seoul, 32 Dongguk-lo, Ilsandong-gu, Goyang-si, Gyeonggi-do 10326, Republic of Korea.

\section{Ethics approval and consent to participate}

Not applicable

Consent for publication

Not applicable

\section{Competing interests}

The authors declare that they have no competing interests.

\section{References}

1. Era M, Matsuo Y, Saito Y, Nishida K, Jiang Z-H, Tanaka T. Ellagitannins and related compounds from Penthorum chinense. J Nat Prod. 2019;82:129-35.

2. Huang D, Jiang Y, Chen W, Yao F, Huang G, Sun L. Evaluation of hypoglycemic effects of poplyphenols and extracts form Penthorum chinense. J Ethnopharmacol. 2015;163:256-63.

3. Huang D, Jiang Y, Chen W, Yao F, Sun L. Polyphenols with anti-proliferative activities from Penthorum chinense Pursh. Molecules. 2014;19:11045-55.

4. Wang A, Li M, Huang H, Xiao Z, Shen J, Zhao Y, Yin J, Kaboli PJ, Cao J, Cho CH, Wang Y, Li J, Wu X. A review of Penthorum chinese Pursh for hepatoprotection: Traditional use, phytochemistry, pharmacology, toxicology and clinical trials. J Ethnopharmacol. 2020;251:112569.

5. Wang A, Lin L, Wang Y. Traditional Chinese herbal medicine Penthorum chinese Pursh: A phytochemical and pharmacological reviews. Am J Chin Med. 2015;43:601-20.

6. Zhao W-W, Guo W-W, Guo J-F, Wang X, Chen X-Q, Wu X. Three new flavonoids from Penthorum chinense Pursh and their docking studies. Nat Prod Res. 2019: 1613394.

7. Sun Z-L, Zhang Y-Z, Zhang F, Zhang J-W, Zheng G-C, Tan L, Wang C-Z, Zhou L-D, Zhang Q-H, Yuan CS. Quality assessment of Penthorum chinense Pursh through multicomponent qualification and fingerprint, chemometric, and antihepatocarcinoma analyses. Food Funct. 2018;9:3807.

8. Yin J, Ren W, Wei B, Huang H, Li M, Wu X, Wang A, Xiao Z, Shen J, Zhao Y, Du F, Ji H, Kaboli PJ, Ma Y, Zhang Z, Cho CH, Wang S, Wu X, Wang Y. Characterization of chemical composition and prebiotic effect of a dietary medicinal plant Penthorum chinese Pursh. Food Chem. 2020;319:126568.

9. Ahn J, Kim Y-M, Chae H-S, Choi YH, Ahn HC, Yoo H, Kang M, Kim J, Chin Y-W. Prenylated flavonoids from the roots and rhizomes of Sophora tonkinensis and their effect on the expression of inflammatory mediator and proprotein convertase subtilisin/kexin type 9. J Nat Prod. 2019;82:30917. 
10. Pel P, Chae H-S, Nhoek P, Kim Y-M, Khiev P, Kim GJ, Nam J-W, Choi H, Choi YH, Chin Y-W. A stilbene dimer and flavonoids from the aerial parts of Chromolaena odorata with proprotein convertase subtilisin/kexin type 9 expression inhibitory activity. Bioorg Chem. 2020;99:103869.

11. Nhoek P, Ahn J, Chae H-S, Pel P, Kim Y-M, Lee SE, Lee JH, Kim J, Choi YH, Lee K, Chin Y-W. Isolation of polyacetylences with proprotein convertase/kexin type 9 downregulating activity and two new sesquiterpenes from the aerial parts of Aster koraiensis. Tetrahedron Lett. 2020;61:151957.

12. Peterson AS, Fong LG, Young SG. PCSK9 function and physiology. J Lipid Res. 2008;49:1595-9.

13. Kjellmo CA, Hovland A, Lappegård K. T. CVD risk stratification in the PCSK era: is there a role for LDL substrations? Diseases. 2018;6:45.

14. Pel P, Chae H-S, Nhoek P, Yeo W, Kim Y-M, Chin Y-W. Lignans from the fuits of Schisandra chinensis (Turcz.) Ball inhibit proprotein convertase subtilisin/kexin type 9 expression. Phytochemistry. 2017;136:119-24.

15. Kwon J, Lee H, Yoon YD, Hwang BY, Guo Y, Kang JS, Kim J-J, Lee D. Lanostane triterpenes isolated from Antrodia heteromorpha and their inhibitory effects on RANKL-induce osteoclastogenesis. J Nat Prod. 2016;79:1689-93.

16. Pescitelli G, Bruhn T. Good computational practice in the assignment of absolute configurations by TDDFT calculation of ECD spectra. Chirality. 2016;28:466-74.

17. Tanaka T, Nakashima T, Ueda T, Tomii K, Kouno I. Facile discrimination of aldose enantiomers by reversed-phase HPLC. Chem Pharm Bull. 2007;55:899-901.

18. Zhang N, Wei S, Cao S, Zhang Q, Kang N, Ding L, Qiu F. Bioactive triterpenoid saponins from the seeds of Aesculus chinensis Bge. var chekiangensis. Front Chem. 2020;7:908.

19. Huang D, Dong Z, Sun L, Chen W, Sun L. Two neolignans from Penthorum chinense and their antiproliferative activities. Nat Prod Res. 2020;34:1515-20.

20. He Y-C, Zou Y, Peng C, Liu J-L, He C-J, Guo L, Xie X-F, Xiong L. Penthorin A and B, two unusual 2,4'epoxy-8,5'-neolignans from. Penthorum chinense Fitoterapia. 2015;100:7-10.

21. He Y-C, Peng C, Xie X-F, Chen M-H, Li X-N, Li M-T, Zhou Q-M, Guo L, Xiong L. Penchinones A-D, two pairs of cis-trans isomers with rearranged neolignane carbon skeletons from Penthorum chinense. RSC Adv. 2015;5:76788.

22. Jung JH, Pummangura S, Chaiichantipyuth C, Patarapanich C, McLaughlin JL. Bioactive constituents of Melodorum fruticosusm Phytochemistry. 1990;29:1667-70.

23. Bjorklund JA, Leete E. Biosynthesis of the benzoyl moiety of cocaine from cinnamic acid via (R)(+)-3-hydroxy-3-phenylpropanoic acid. Phytochemistry. 1992;31:3883-7.

24. Afsar T, Khan MR, Razak S, Ullah S, Mirza B. Antipyretic, anti-inflammatory and analgesic activity of Acacia hydaspica R. Parker and its phytochemical analysis. BMC Complem Altern Med. 2015;15:136.

25. Zeng Y, Sun Y-X, Meng X-H, Yu T, Zhu H-T, Zhang Y-J. A new methylene bisflavan-3-ol from the branches and leaves of Potentilla fruticosa. Nat Prod Res. 2020;34:1238-45. 
26. Liu Q, Zhang Y-J, Yang C-R, Xu M. Phenolic antioxidants from green tea produced from Camellia crassicolumna var. multiplex J Agric Food Chem. 2009;57:586-90.

27. Zhang L, Tu Z-C, Yuan T, Ma H, Niesen DB, Wang H, Seeram NP. New gallotannin and other phytochemicals from sycamore maple (Acer pseudoplatanus) leaves. Nat Prod Commun. 2015;10:1977-80.

28. Zemplén G, Bognár R, Mechner J. synthese des glucosids torignin. Chem Ber. 1944;77:99-105.

29. Pompermaier L, Heiss EH, Alilou M, Mayr F, Monizi M, Lautenschlaeger T, Schuster D, Schawaiger S, Stuppner H. Dihydrochalcone glucosides from the subaerial parts of Thonningia sangsuinea and their in vitro PTP1B inhibitory activities. J Nat Prod. 2018;81:2091-100.

30. Xu J, Yang L, Zhao S-J, Chou G-X, Wang Z-T.. Microbial glycosylation of cardamonin by Mucor spinosus. Yao Xue Bao. 2011;46:733-7.

31. Chormova D, Franková L, Defries A, Cutler SR, Fry SC. Discovery of small molecule inhibitors of xyloglucan endotransglucosylase (XET) activity by high-throughput screening. Phytochemistry. 2015;117:220-36.

32. Gao D-F, Xu M, Yang C-R, Xu M, Zhang Y-J. Phenolic antioxidants from the leaves of Camellia pachysandra Hu. J Agric Food Chem. 2010;58:8820-4.

33. An HJ, Kim EH, Lee HL, Cho J-Y, Moon J-H. New caryophyllene-type sesquiterpene and flavonol tetraglycoside with sixteen known compounds from sword been (Canavalia gladiate). Food Sci Biotechnol. 2020;29:1343-53.

34. Guo W-W, Wang X, Chen X-G, Ba Y-Y, Zhang N, Xu R-R, Zhao W-W, Wu X. Flavonones from Penthorum chinense ameliorate hepatic steatosis by activating the SIRT1/AMPK pathway in HepG2 cells. Int J Mol Sci. 2018;19:2555.

35. Guo WW, Jiang Y, Chen X, Yu P, Wu X, Zhang D. Identification and quantitation of major phenolic compounds from Penthorum chinense Pursh by HPLC with tandem mass spectrometry and HPLC with diode array detection. J Sep Sci. 2015;38:2789-96.

36. Hong SS, Jeong W, Lee JY, Ahn E-K, Oh JS. Inhibition of antigen-induced degranulation by flavonoids isolated from the leaves of Quercus acuta in RBL-2H3 cells. Chem Nat Compd. 2016;52:1089-92.

37. Yang N-Y, Tao W-W, Duan J-A. Antithrombotic flavonoids from the faeces of Trogopterus xanthipes. Nat Prod Res. 2010;24:1843-9.

38. Han J-T, Bang M-H, Chun O-K, Kim D-O, Lee C-Y, Baek N-I. Flavonol glycosides from the aerial parts of Aceriphyllum rolssii and their antioxidant activities. Arch Pharm Res. 2004;27:390-5.

39. Xu J, Wang X, Yue J, Sun Y, Zhang X. ZhaoY. Polyphenols from acorn leaves (Quercus liaotungensis) protect pancreatic beta cells and their inhibitory activity against $a-$ glucosidase and protein tyrosine phosphatase 1B. Molecules. 2018;23:2167.

40. Lin X-L, Xiao L-L, Tang Z-H, Jiang Z-S, Liu M-H. Role of PCSK9 in lipid metabolism and atherosclerosis. Biomed Pharmacother. 2018;104:36-44. 
41. Skeik N, Nowariak ME, Smith JE, Alexander JQ, Manunga JM, Mirza AK, Sullivan TM. Lipid-lowering therapies in peripheral artery disease: A review. Vasc. Med. 2020;1358863 × 20957091. (in press).

42. Mayne J, Dewpura T, Raymond A, Cousins M, Chaplin A, Lahey KA, LaHaye SA, Mbikay M, Ooi TC, Chrétien M. Plasma PCSK9 levels are significantly modified by statins and fibrates in human. Lipids Health Dis. 2008;7:22.

43. Dubuc G, Chamberland A, Wassef H, Davignon J, Seidah NG, Bernier L, Prat A. Statins upregulate PCSK9, the gene encoding the proprotein convertase neural apoptosis-regulated convertase-1 implicated in faminlial hypercholesterolemia. Arterioscler ThrombVasc Biol. 2004;24:1454-9.

44. Xu S, Luo S, Zhu Z, Xu J. Small molecules as inhibitors of PCSK9: Current status and future challenges. Eur J Med Chem. 2019;162:212-33.

\section{Figures}


<smiles>[R2]c1cc2c(cc1/C=C/C)Oc1c(ccc([R2])c1[R])C(=O)C2([R3])[R]</smiles>

$1 \mathrm{R}_{1}=\mathrm{OCH}_{3}, \mathrm{R}_{2}=\mathrm{R}_{3}=\mathrm{OH}, \mathrm{R}_{4}=\mathrm{CH}_{3}, \mathrm{R}_{5}=\mathrm{H}$

$2 \mathrm{R}_{1}=\mathrm{R}_{3}=\mathrm{OH}, \mathrm{R}_{2}=\mathrm{OCH}_{3}, \mathrm{R}_{4}=\mathrm{CH}_{3}, \mathrm{R}_{5}=\mathrm{H}$

$3 \mathrm{R}_{1}=\mathrm{OCH}_{3}, \mathrm{R}_{2}=\mathrm{R}_{3}=\mathrm{R}_{5}=\mathrm{OH}, \mathrm{R}_{4}=\mathrm{CH}_{3}$

$4 \mathrm{R}_{1}=\mathrm{OCH}_{3}, \mathrm{R}_{2}=\mathrm{R}_{5}=\mathrm{OH}, \mathrm{R}_{3}=\mathrm{CH}_{3}, \mathrm{R}_{4}=\mathrm{H}$<smiles>O=C1CCOc2cc(O)cc(O)c21</smiles><smiles>C/C=C/c1cc2c(cc1O)Oc1c(ccc(O)c1OC)[C@H]2C(C)=O</smiles>

5<smiles>O=C(O)C[C@H](C(=O)OC[C@H]1O[C@H](OC(=O)c2cc(O)c(O)c(O)c2)[C@@H](O)[C@H](O)[C@H]1O)[C@@H]1c2c(cc(O)c(O)c2O)C(=O)O[C@H]1C(=O)O</smiles><smiles>O=C(O)CC(O)c1ccccc1</smiles>

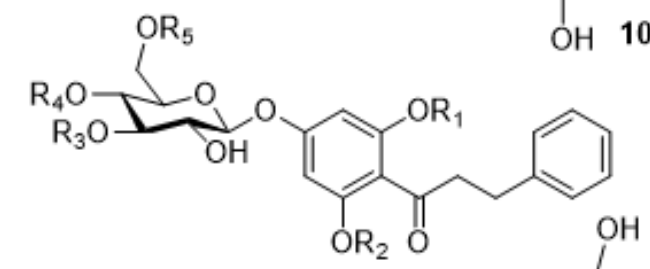

$15 \mathrm{R}_{1}=\mathrm{CH}_{3}, \mathrm{R}_{2}=\mathrm{R}_{3}=\mathrm{R}_{4}=\mathrm{R}_{5}=\mathrm{H}$

$16 \mathrm{R}_{1}=\mathrm{R}_{2}=\mathrm{R}_{3}=\mathrm{R}_{4}=\mathrm{R}_{5}=\mathrm{H}$

$17 \mathrm{R}_{1}=\mathrm{R}_{2}=\mathrm{R}_{4}=\mathrm{R}_{5}=\mathrm{H}, \mathrm{R}_{3}=\mathrm{G} 1$

$18 \mathrm{R}_{1}=\mathrm{R}_{2}=\mathrm{R}_{3}=\mathrm{H}, \mathrm{R}_{4}+\mathrm{R}_{5}=\mathrm{G} 2$

$19 R_{1}=R_{2}=H, R_{3}=G 1, R_{4}+R_{5}=G 2$<smiles>[R][X][C@@H]1Cc2c(O)cc(OC(=O)c3cc(O)c(O)c(O)c3)cc2O[C@H]1c1ccc(O)c(O)c1</smiles>

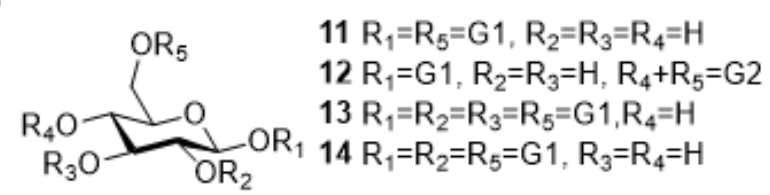<smiles>[R2]Oc1c(-c2ccc(O)c([R2])c2)oc2cc(O)cc(O)c2c1=O</smiles>

$32 \mathrm{R}_{1}=$ ara, $\mathrm{R}_{2}=\mathrm{OH}$

$33 \mathrm{R}_{1}=$ rha, $\mathrm{R}_{2}=\mathrm{H}$

$34 \mathrm{R}_{1}=\mathrm{rha}, \mathrm{R}_{2}=\mathrm{OH}$

$35 \mathrm{R}_{1}=\mathrm{H}, \mathrm{R}_{2}=\mathrm{OH}$

$36 \mathrm{R}_{1}=\mathrm{R}_{2}=\mathrm{H}$

$37 \mathrm{R}_{1}=\mathrm{glc}, \mathrm{R}_{2}=\mathrm{H}$

$38 \mathrm{R}_{1}=$ glc, $\mathrm{R}_{2}=\mathrm{OH}$<smiles>[R20]OC(=O)c1cc([R])c(O)c(O)c1</smiles>

$22 \mathrm{R}_{1}=\mathrm{R}_{2}=\mathrm{H}$

$23 \mathrm{R}_{1}=\mathrm{OH}, \mathrm{R}_{2}=\mathrm{glc}$

$24 \mathrm{R}_{1}=\mathrm{OH}, \mathrm{R}_{2}=\mathrm{H}$

$25 \mathrm{R}_{1}=\mathrm{OH}, \mathrm{R}_{2}=\mathrm{CH}_{3}$<smiles>[R20]CC1OC(Oc2cc(O)c(C(C)=O)c(O)c2)C(O)C(O)C1O[R20]</smiles>

$26 \mathrm{R}_{1}=\mathrm{R}_{2}=\mathrm{H}$

$27 \mathrm{R}_{1}+\mathrm{R}_{2}=\mathrm{G} 2$

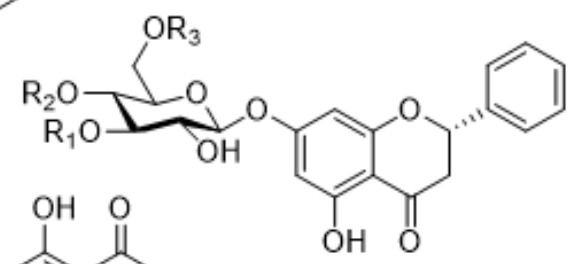

$28 \mathrm{R}_{1}=\mathrm{R}_{2}=\mathrm{R}_{3}=\mathrm{H}$

$29 R_{1}=R_{2}=H, R_{3}=G 1$

$30 \mathrm{R}_{1}=\mathrm{H}, \mathrm{R}_{2}+\mathrm{R}_{3}=\mathrm{G} 2$

$31 R_{1}=G 1, R_{2}+R_{3}=G 2$<smiles>CC(=O)c1cc(O)c(O)c(O)c1</smiles>

\section{Figure 1}

Isolated compounds from the aerial parts of P. chinense 
<smiles>[R2]c1cc2c(cc1/C=C/C)Oc1c(ccc([R2])c1[R])C(=O)C2([R3])[R]</smiles>

$1 \mathrm{R}_{1}=\mathrm{OCH}_{3}, \mathrm{R}_{2}=\mathrm{R}_{3}=\mathrm{OH}, \mathrm{R}_{4}=\mathrm{CH}_{3}, \mathrm{R}_{5}=\mathrm{H}$

$2 \mathrm{R}_{1}=\mathrm{R}_{3}=\mathrm{OH}, \mathrm{R}_{2}=\mathrm{OCH}_{3}, \mathrm{R}_{4}=\mathrm{CH}_{3}, \mathrm{R}_{5}=\mathrm{H}$

$3 \mathrm{R}_{1}=\mathrm{OCH}_{3}, \mathrm{R}_{2}=\mathrm{R}_{3}=\mathrm{R}_{5}=\mathrm{OH}, \mathrm{R}_{4}=\mathrm{CH}_{3}$

$4 \mathrm{R}_{1}=\mathrm{OCH}_{3}, \mathrm{R}_{2}=\mathrm{R}_{5}=\mathrm{OH}, \mathrm{R}_{3}=\mathrm{CH}_{3}, \mathrm{R}_{4}=\mathrm{H}$<smiles>O=C1CCOc2cc(O)cc(O)c21</smiles><smiles>C/C=C/c1cc2c(cc1O)Oc1c(ccc(O)c1OC)[C@H]2C(C)=O</smiles>

5<smiles>O=C(O)C[C@H](C(=O)OC[C@H]1O[C@H](OC(=O)c2cc(O)c(O)c(O)c2)[C@@H](O)[C@H](O)[C@H]1O)[C@@H]1c2c(cc(O)c(O)c2O)C(=O)O[C@H]1C(=O)O</smiles><smiles>O=C(O)CC(O)c1ccccc1</smiles>

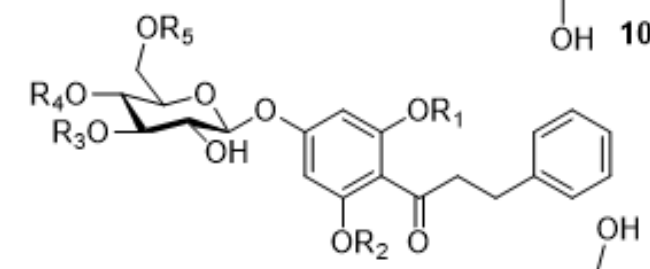

$15 \mathrm{R}_{1}=\mathrm{CH}_{3}, \mathrm{R}_{2}=\mathrm{R}_{3}=\mathrm{R}_{4}=\mathrm{R}_{5}=\mathrm{H}$

$16 \mathrm{R}_{1}=\mathrm{R}_{2}=\mathrm{R}_{3}=\mathrm{R}_{4}=\mathrm{R}_{5}=\mathrm{H}$

$17 \mathrm{R}_{1}=\mathrm{R}_{2}=\mathrm{R}_{4}=\mathrm{R}_{5}=\mathrm{H}, \mathrm{R}_{3}=\mathrm{G} 1$

$18 \mathrm{R}_{1}=\mathrm{R}_{2}=\mathrm{R}_{3}=\mathrm{H}, \mathrm{R}_{4}+\mathrm{R}_{5}=\mathrm{G} 2$

$19 R_{1}=R_{2}=H, R_{3}=G 1, R_{4}+R_{5}=G 2$<smiles>[R][X][C@@H]1Cc2c(O)cc(OC(=O)c3cc(O)c(O)c(O)c3)cc2O[C@H]1c1ccc(O)c(O)c1</smiles>

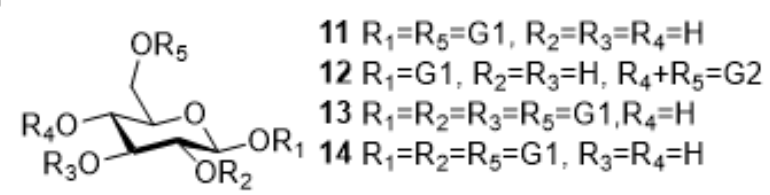<smiles>[R2]Oc1c(-c2ccc(O)c([R2])c2)oc2cc(O)cc(O)c2c1=O</smiles>

$32 \mathrm{R}_{1}=$ ara, $\mathrm{R}_{2}=\mathrm{OH}$

$33 \mathrm{R}_{1}=$ rha, $\mathrm{R}_{2}=\mathrm{H}$

$34 \mathrm{R}_{1}=\mathrm{rha}, \mathrm{R}_{2}=\mathrm{OH}$

$35 \mathrm{R}_{1}=\mathrm{H}, \mathrm{R}_{2}=\mathrm{OH}$

$36 \mathrm{R}_{1}=\mathrm{R}_{2}=\mathrm{H}$

$37 \mathrm{R}_{1}=\mathrm{glc}, \mathrm{R}_{2}=\mathrm{H}$

$38 \mathrm{R}_{1}=$ glc, $\mathrm{R}_{2}=\mathrm{OH}$<smiles>[R20]OC(=O)c1cc([R])c(O)c(O)c1</smiles>

$22 \mathrm{R}_{1}=\mathrm{R}_{2}=\mathrm{H}$

$23 \mathrm{R}_{1}=\mathrm{OH}, \mathrm{R}_{2}=\mathrm{glc}$

$24 \mathrm{R}_{1}=\mathrm{OH}, \mathrm{R}_{2}=\mathrm{H}$

$25 \mathrm{R}_{1}=\mathrm{OH}, \mathrm{R}_{2}=\mathrm{CH}_{3}$<smiles>[R20]CC1OC(Oc2cc(O)c(C(C)=O)c(O)c2)C(O)C(O)C1O[R20]</smiles>

$26 \mathrm{R}_{1}=\mathrm{R}_{2}=\mathrm{H}$

$27 \mathrm{R}_{1}+\mathrm{R}_{2}=\mathrm{G} 2$

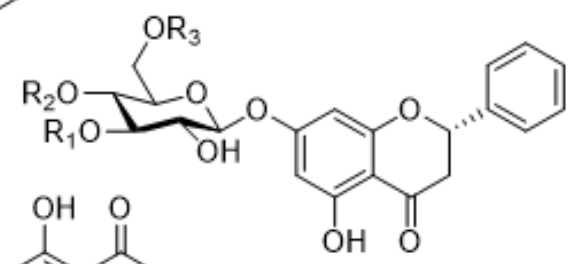

$28 \mathrm{R}_{1}=\mathrm{R}_{2}=\mathrm{R}_{3}=\mathrm{H}$

$29 R_{1}=R_{2}=H, R_{3}=G 1$

$30 \mathrm{R}_{1}=\mathrm{H}, \mathrm{R}_{2}+\mathrm{R}_{3}=\mathrm{G} 2$

$31 R_{1}=G 1, R_{2}+R_{3}=G 2$<smiles>CC(=O)c1cc(O)c(O)c(O)c1</smiles>

\section{Figure 1}

Isolated compounds from the aerial parts of P. chinense 
A
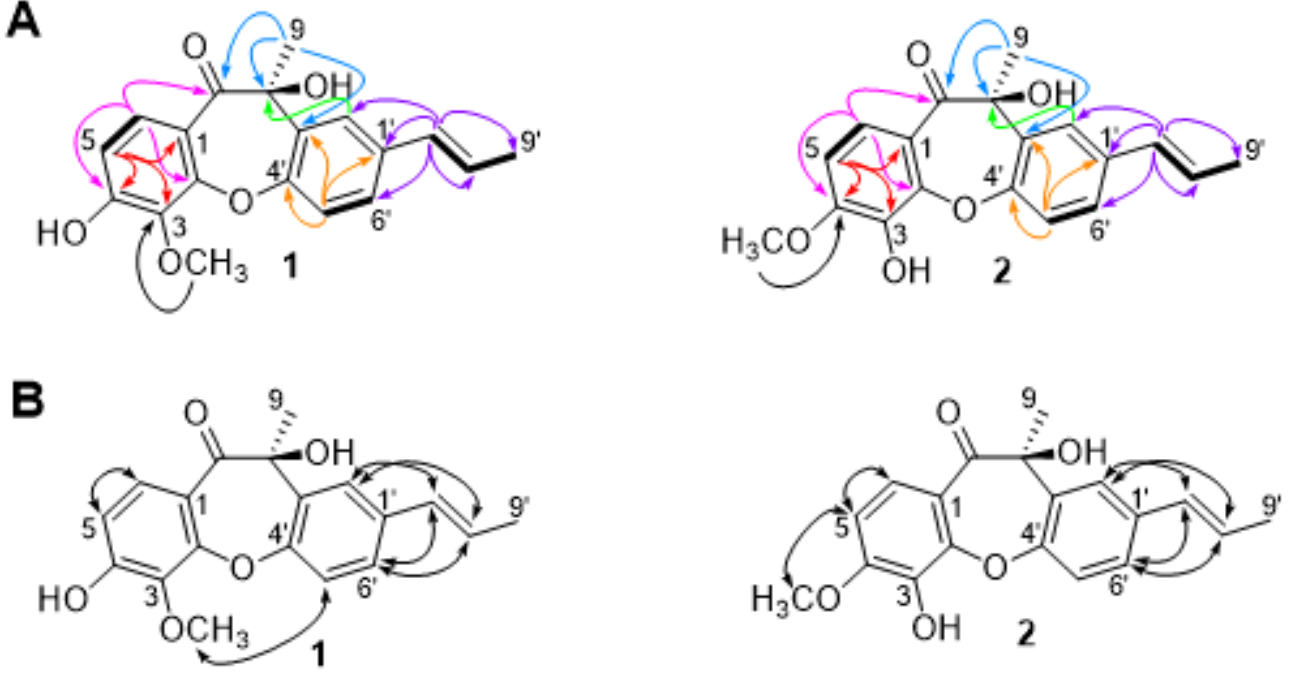

Figure 2

A) Key $1 \mathrm{H}-1 \mathrm{H}$ COSY $(\boldsymbol{\square})$ and HMBC $(\rightarrow)$ correlations; (B) Selective key NOESY $(\leftrightarrow)$ correlations of compounds 1 and 2 .

A
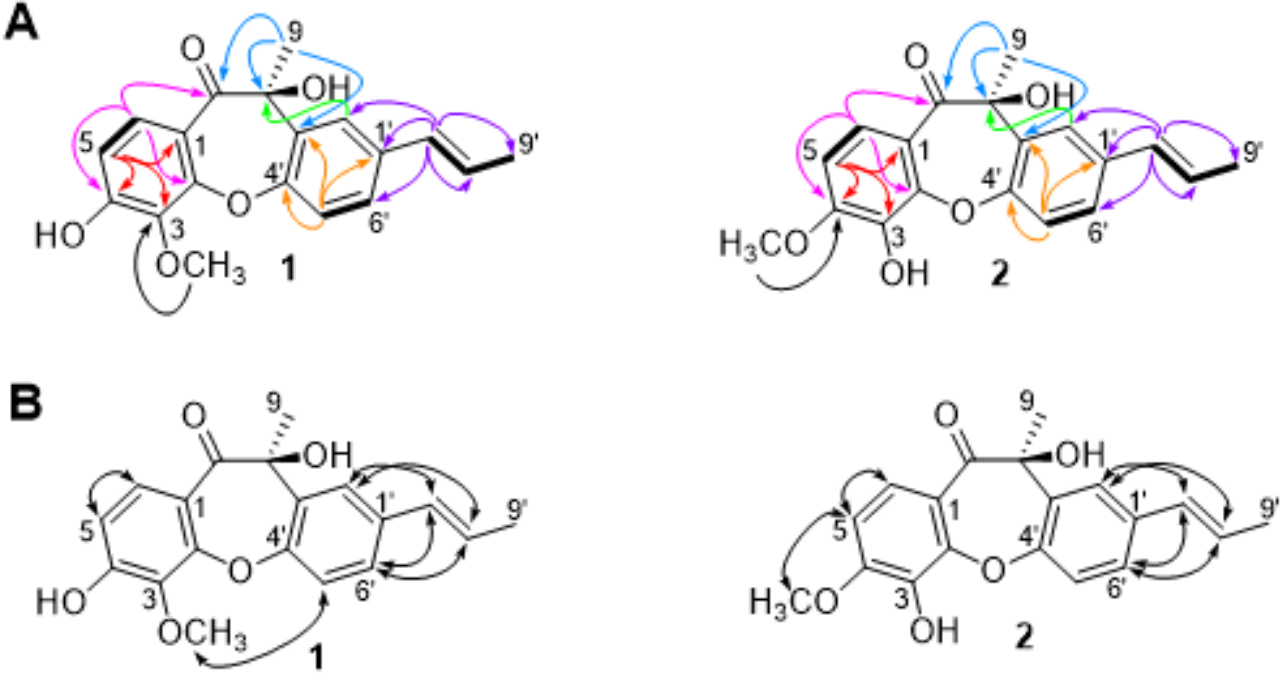

Figure 2

A) Key $1 \mathrm{H}-1 \mathrm{H} \operatorname{COSY}(\boldsymbol{\square})$ and HMBC $(\rightarrow)$ correlations; (B) Selective key NOESY $(\leftrightarrow)$ correlations of compounds 1 and 2 . 


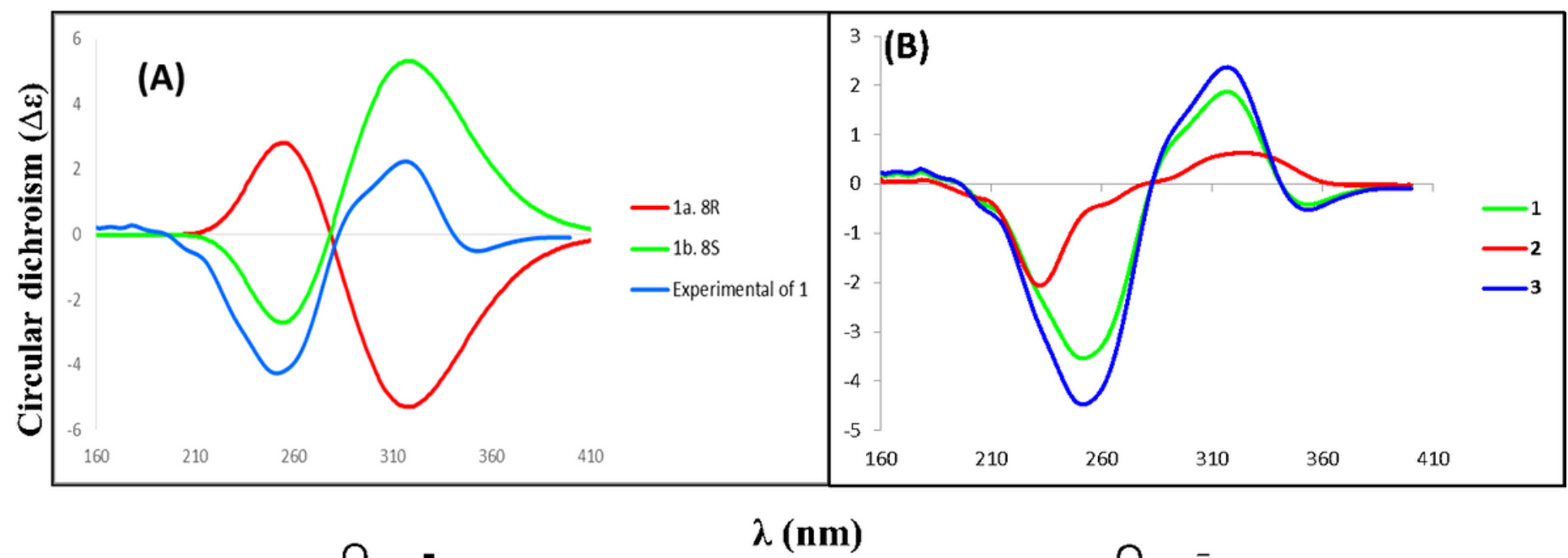<smiles>C/C=C/c1ccc2c(c1)[C@@](C)(O)C(=O)c1ccc(O)c(OC)c1O2</smiles>

1a. $8 R$<smiles>C/C=C/c1ccc2c(c1)[C@@](C)(O)C(=O)c1ccc(O)c(OC)c1O2</smiles>

1b. $8 S$

Figure 3

(A) Experimental and calculated ECD curves for compound 1. (B) Experimental for compounds 1, 2, and 3.

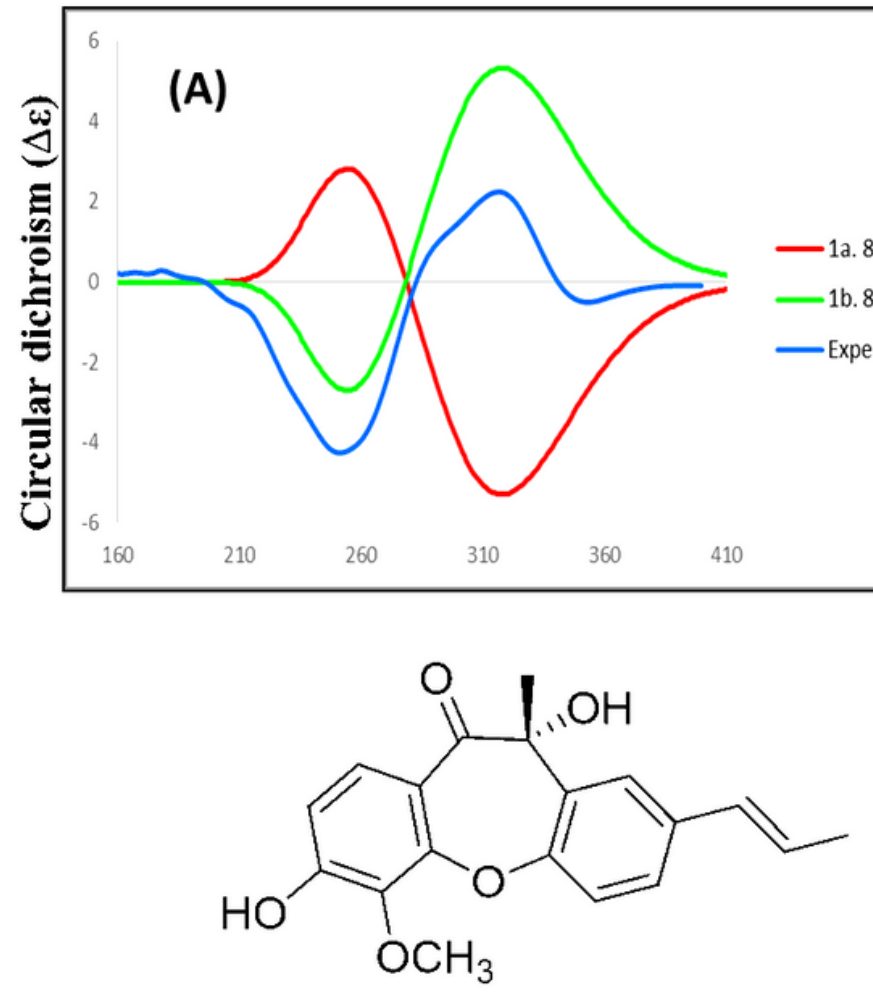

1a. $8 R$

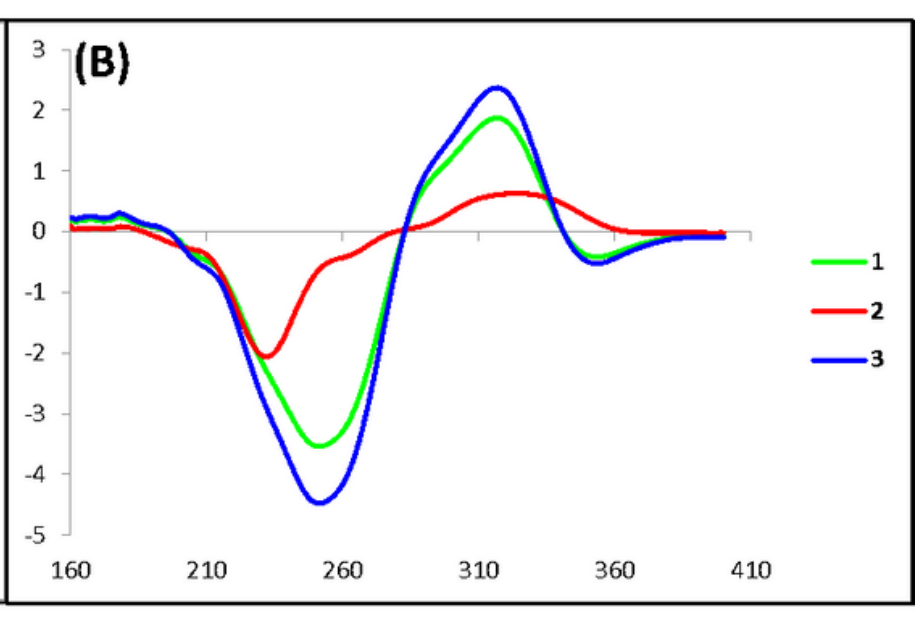

$\lambda(\mathbf{n m})$<smiles>C/C=C/c1ccc2c(c1)[C@@](C)(O)C(=O)c1ccc(O)c(OC)c1O2</smiles>

1b. 85 
Figure 3

(A) Experimental and calculated ECD curves for compound 1. (B) Experimental for compounds 1, 2, and 3.

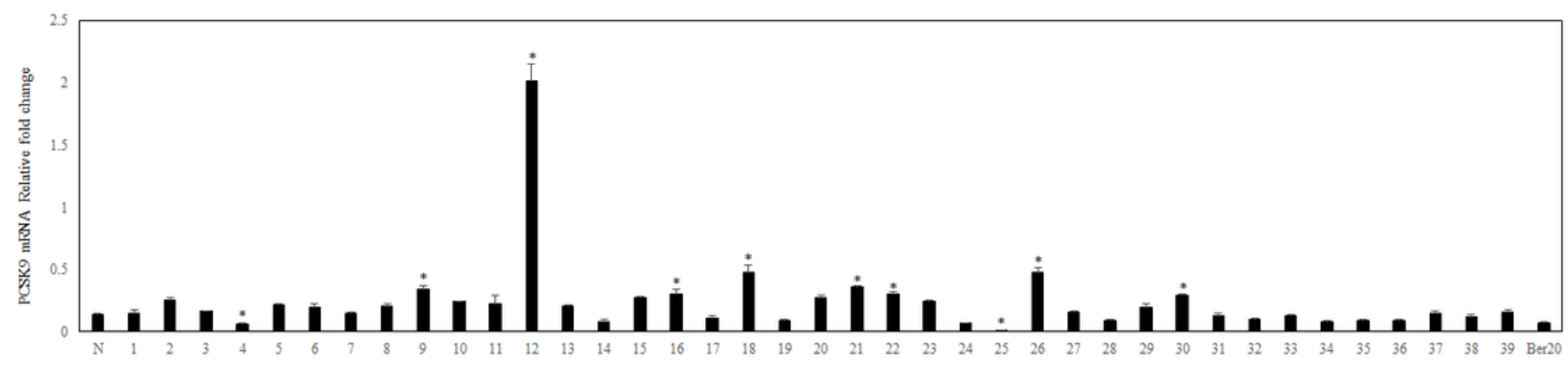

Figure 4

Effect of compounds from P. chinense on PCSK9 inhibition in the HepG2 human hepatocellular liver carcinoma cell line. Expression of PCSK9 was assayed by qRT-PCR in cells treated with compounds (50 $\mu \mathrm{M})$, and berberine (Ber20, $20 \mu \mathrm{M})$ for $24 \mathrm{~h}$.

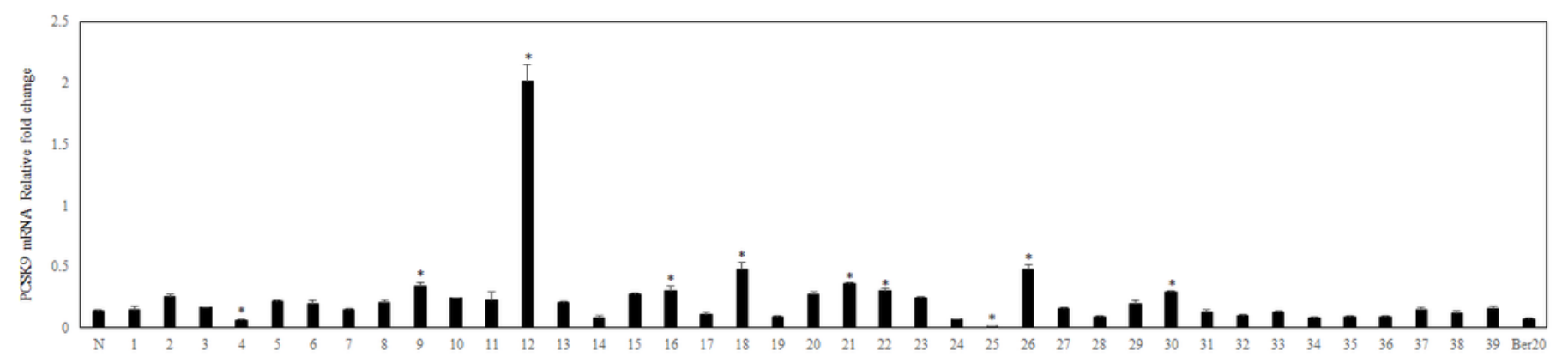

Figure 4

Effect of compounds from P. chinense on PCSK9 inhibition in the HepG2 human hepatocellular liver carcinoma cell line. Expression of PCSK9 was assayed by qRT-PCR in cells treated with compounds (50 $\mu \mathrm{M})$, and berberine (Ber20, $20 \mu \mathrm{M})$ for $24 \mathrm{~h}$. 

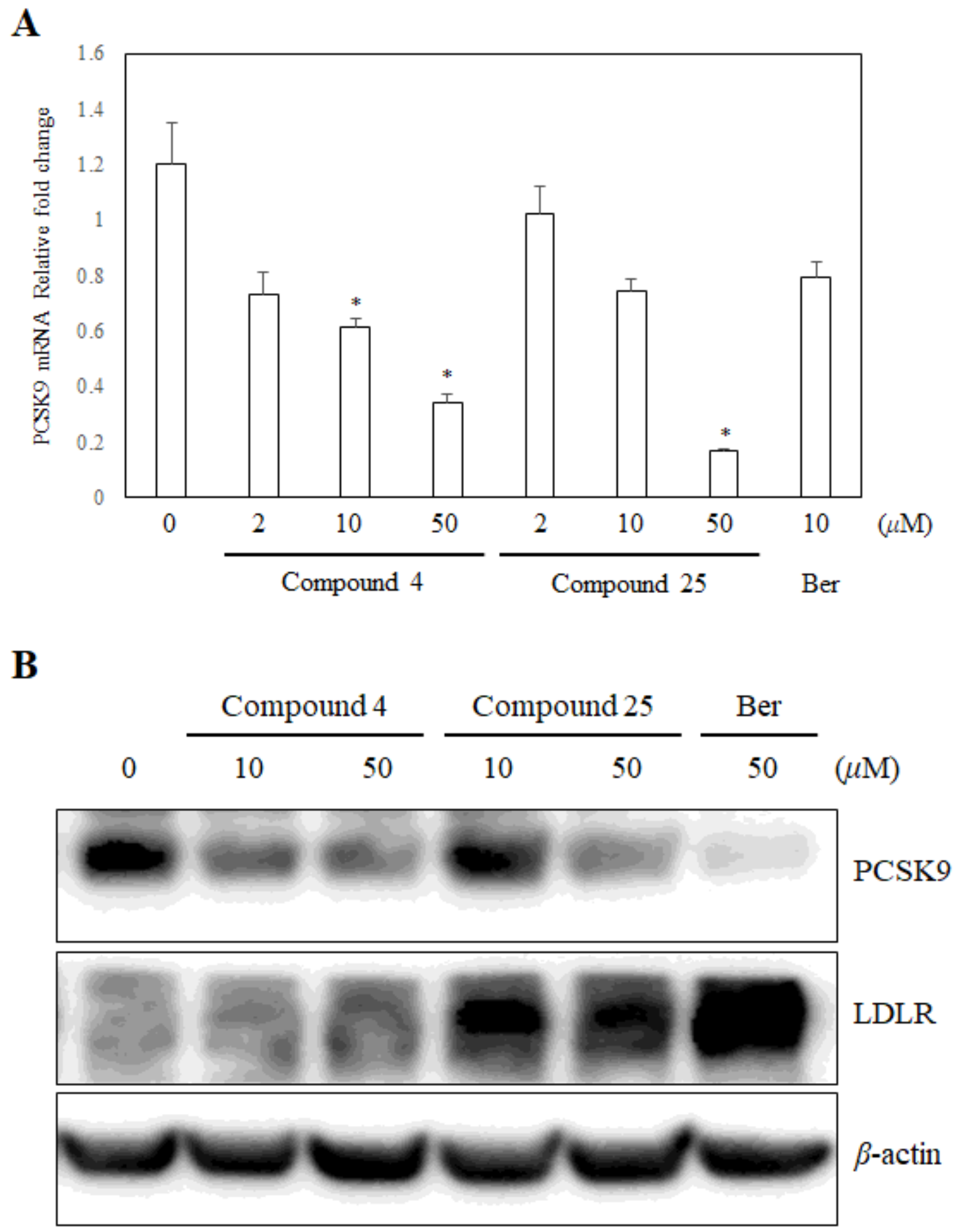

Figure 5

Effect of compounds 4 and 25 on PCSK9 and LDLR in the HepG2 human hepatocellular liver carcinoma cell line. (A) Expression of PCSK9 was assayed by qRT-PCR in cells treated with compounds 4 and 25 (2, 10 and $50 \mu \mathrm{M}$ ), and berberine (Ber, $10 \mu \mathrm{M}$ ) for $24 \mathrm{~h}$. (B) Expression of PCSK9 and LDL-R were assayed by western blot in cells treated with compounds (10 and $50 \mu \mathrm{M})$, and berberine (Ber, $50 \mu \mathrm{M})$ for $24 \mathrm{~h}$. ${ }^{*} \mathrm{p}<0.05$. 

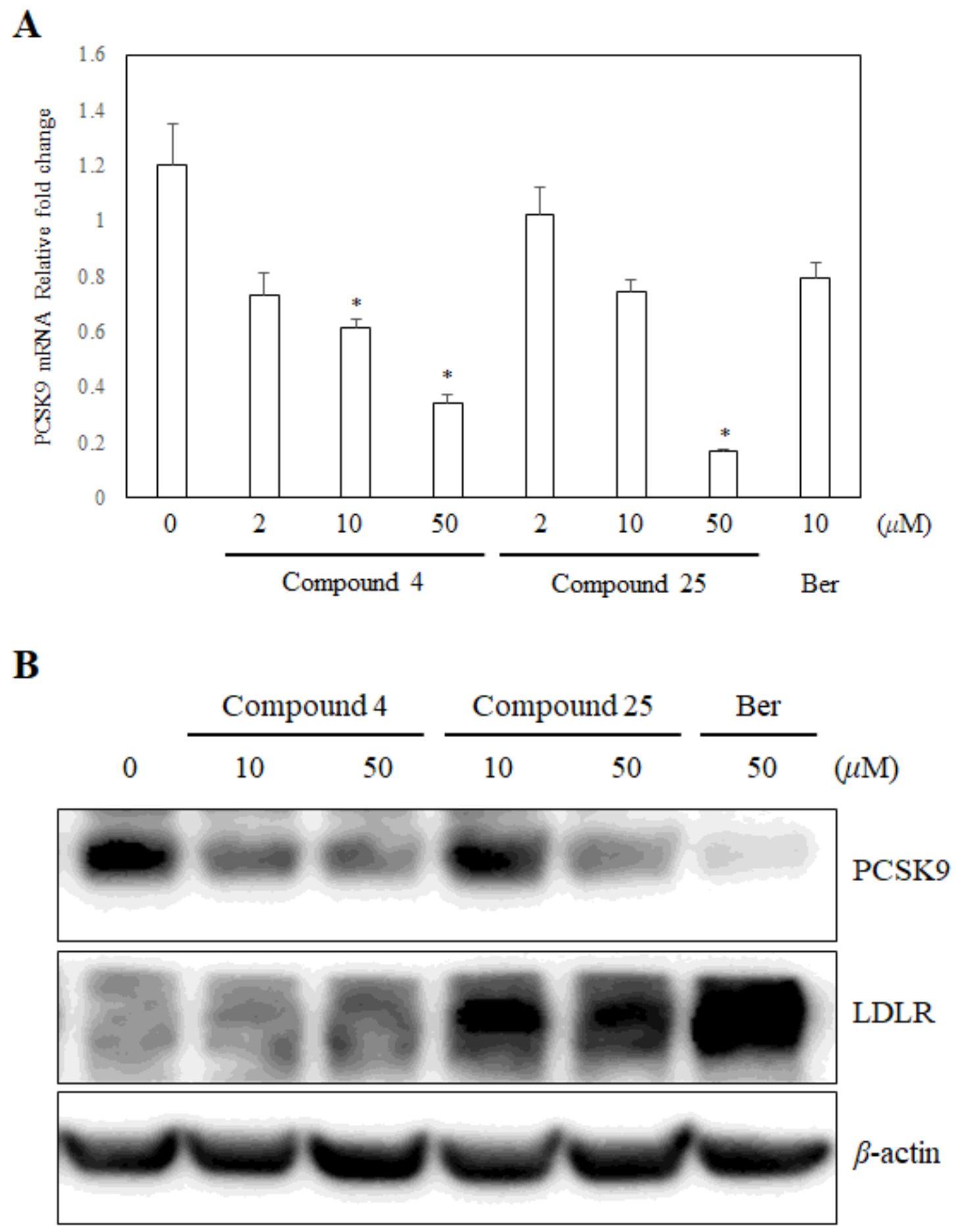

Figure 5

Effect of compounds 4 and 25 on PCSK9 and LDLR in the HepG2 human hepatocellular liver carcinoma cell line. (A) Expression of PCSK9 was assayed by qRT-PCR in cells treated with compounds 4 and 25 (2, 10 and $50 \mu \mathrm{M}$ ), and berberine (Ber, $10 \mu \mathrm{M}$ ) for $24 \mathrm{~h}$. (B) Expression of PCSK9 and LDL-R were assayed by western blot in cells treated with compounds (10 and $50 \mu \mathrm{M})$, and berberine (Ber, $50 \mu \mathrm{M})$ for $24 \mathrm{~h}$. ${ }^{*} \mathrm{p}<0.05$. 


\section{Supplementary Files}

This is a list of supplementary files associated with this preprint. Click to download.

- supportinginformationcyw.docx

- supportinginformationcyw.docx 